\title{
Electrical Data Release: Natural Source Telluric Traverses and Audio-magnetotelluric Soundings Near Las Vegas, North-Central Clark County, Nevada
}

by

Herbert A. Pierce ${ }^{1}$ and Donald B. Hoover ${ }^{1}$

Open-File Report 88-212

1987

This report is preliminary and has not been reviewed for conformity with U.S. Geological Survey editorial standards. Any use of trade names is for descriptive purposes only and does not imply endorsement by the USGS.

${ }^{1}$ U.S. Geological Survey, Box 25046, Denver Federa1 Center, MS 964 , Lakewood, Co 80225 


\section{Introduction}

During November 1985, six telluric traverses and sixteen audiomagnetotelluric (AMT) soundings were made in north-central clark County, Nevada. The soundings and traverses were performed in conjunction with work by other USGS earth scientists as part of the Nevada carbonate-aquifers project. The electrical data to aid the geologic investigation of a very complex hydrologic flow system by mapping the electrical response and apparent resistivity of structures and by defining boundaries not readily visible through other surface mapping techniques.

\section{The Audio-magnetotelluric method}

The magnetotelluric (MT) method is an electromagnetic sounding method in which variations in earth resistivity as a function of depth are measured (Keller and Frischknecht, 1966). These soundings are obtained by measuring the earth's surface electromagnetic fields at different frequencies. Because lower frequency electromagnetic waves penetrate further into the earth than higher frequency ones before they are absorbed, measurement of the electromagnetic fields over a broad frequency range gives information on resistivity variations with depth. If these measurements are made in the audio-frequency range then the technique is called the audio-magnetotelluric (AMT) method. This method is discussed in detail by Strangway and others (1973) and the application and details of the USGS AMT system are given by Hoover and others $(1976,1978)$ and Hoover and Long (1976).

Calculating the apparent resistivity from AMT measurements is identical to the procedure used for MT measurements. The AMT system measures both the electric field (E-field) and the magnetic field (H-field) at each frequency. Amplitudes of corresponding electric and magnetic field pulses are digitized and calculations of apparent resistivity are made, using the following Cagniard equation:

$$
\rho_{a}=1 / 5 f[E / H]^{2}
$$

where $\rho_{a}$ is apparent resistivity in ohm-m, and $f$ is frequency in $\mathrm{Hz}$. $E$ is the E-field magnitude in $\mathrm{mv} / \mathrm{km}$ and $\mathrm{H}$ is the $\mathrm{H}$-field magnitude in gammas.

The depth of exploration of the AMT methods is not only a function of frequency, but also of the resistivity of the volume of earth sampled. For a homogeneous earth the maximum depth of exploration (D) in meters can be approximated by a relationship given by Bostick (1977),

$$
D=355 \sqrt{\rho_{a} / f}
$$

where $\rho_{a}$ is the half-space resistivity in ohm-m, and $f$ is the frequency in $\mathrm{Hz}$.

As in any sounding technique it should be remembered that the earth is being sampled laterally as well as vertically below the measuring station. Thus, in areas of complex geology, one-dimensional model interpretations may be significantly biased and not represent the vertical distribution of resistivity beneath the sounding site. 
Sources of AMT signals may be either artificial or natural. The USGS equipment used in this survey has been designed for use with natural

sources. The principal source of natural electromagnetic energy in the audiofrequency range is electrical discharge during lightning storms. Typically the signal strength is low except when generated by local storms. The low signal strength can result in poor quality data, especially in the 1 to $4 \mathrm{KHz}$ frequency range where the energy is attenuated by propagation in the earthionosphere waveguide. The limitations of natural source AMT exploration are discussed more fully by Hoover and others (1978).

The AMT soundings presented here used $25 \mathrm{~m}$-long telluric dipoles except for four soundings on the telluric sites. The Coyote telluric site used 125 $\mathrm{m}$-long dipoles and Cow Camp, Corn Creek, and Moapa telluric sites used $250 \mathrm{~m}-$ long dipoles. The induction sensor and receiving system were are all built by the USGS.

\section{The Telluric Traverse Method}

The telluric traverse (TT) method employs natural earth currents (telluric currents) at various frequencies to measure, indirectly, changes in earth resistivity along a traverse. It was used as early as 1921 (Leonardon, 1928 ) by $C$. Schlumberger, but until recently has not been used very much in the United States. Beyer (1977) discusses the method in some detail and presents a series of results computed for two-dimensional structures. He concludes that the method is well suited for rapid reconnaissance of regions several hundred square-kilometers in area when searching for targets such as hydrothermal systems. The method should be applicable as well when searching for fossil hydrothermal systems and related mineral deposits, because rock alteration will remain after the hydrothermal convection cells have ceased. We have found that the technique is also very useful in mapping faults and other boundaries.

In applying the technique, a receiving array of three electrodes spaced equidistant and in line is used. This array is, in effect, two colinear dipoles sharing a common electrode. The potential difference across each dipole is proportional to the component of the telluric field in the direction of the array. This configuration permits the measurement of the telluric field at each dipole in the direction of the dipole line. The traverse data are extended by moving the three-electrode array forward one dipole length so that the forward electrode becomes the center electrode for the next ratio measurement. This process is repeated for as long as desired.

Telluric measurements are made in a narrow frequency band typically using micropulsation with periods of about 30 seconds $(0.033 \mathrm{~Hz})$, but may be made over a wide range of frequencies. Because lower frequency electromagnetic signals penetrate deeper than higher frequencies, one can, to some extent, select a maximum depth of exploration. The relationship for maximum exploration depth is the same as for AMT work (equation 2). Frequencies selected for this survey were $7.5,16.7$, and $27 \mathrm{~Hz}$. The apparent resistivities ranged from about $100 \mathrm{ohm}-\mathrm{m}$ to over 20,000 ohm $-\mathrm{m}$ at depth. The maximum depth of penetration varied from 0.7 to over $7 \mathrm{Km}$ depending upon the apparent resistivities. The telluric receiver used was of USGS design and manufacture. 


\section{Discussion}

One of the advantages of using the telluric method is the ability to quickly profile relative changes in the earth's electrical structure. If one also performs an AMT sounding on one dipole of the traverse the relative changes can be tied to apparent resistivities. This holds if the traverse is perpendicular to structures and transverse magnetic (TM) mode is assumed. The telluric ratios are then proportional to the square of the resistivities. This was done on Coyote, Moapa, Cow Camp, and Corn Creek Springs telluric traverses to get an idea of the resistivities along the telluric traverses.

Figure 1 shows the locations of the 6 telluric traverses. The Coyote and Moapa telluric traverses were made because they were constrained by geologic data and provided a base to further interpret the natural source EM information obtained near Cow Camp and Corn Creek Springs to the southwest.

Figure 2 shows the locations of the AMT stations. Plots of the AMT data can be found in appendix no. 2 .

Figure 3 is a detailed location map of the Coyote telluric traverse (TT) and audio-magnetotelluric (AMT) stations LVW1 and LVW2. AMT station LVW1 is about $75 \mathrm{~m}$ northeast of the telluric line and AMT station LVW2 is located on the telluric line near electrode position 0 . Electrode position 0 is about 10 $m$ west of the MX4 and MX5 wells. The TT line crosses a thin paleozoic limestone ridge west of the MX4 and MX5 we11s. Because the ridge is very narrow $(<50 \mathrm{~m})$ with the Muddy Creek Formation to the east and west, $125 \mathrm{~m}$ dipoles were used along the $1.5 \mathrm{~km}$ traverse to better define the structures. Figure 4 shows the relative telluric voltages for $7.5,16.7$, and $25 \mathrm{~Hz}$ offset one decade from one another for clarity. The highest relative voltages occur at dipole positions $0-1 \mathrm{~W}$ and $0-1 \mathrm{E}$ with relative voltages dropping off both to the northeast and southwest. An AMT sounding (figure 5) using the $125 \mathrm{~m}-1$ ong dipole $0-1 \mathrm{~W}$ was made to give an absolute reference to the telluric data. Apparent resistivities of about 4,000, 7,000, and 12,000 ohm-m were measured using $25,16.7$, and $7.5 \mathrm{~Hz}$ frequencies respectively. The steps on the telluric traverse relative voltage curves at dipole positions $2 \mathrm{~W}-3 \mathrm{~W}, 2 \mathrm{E}-3 \mathrm{E}$, and $5 \mathrm{E}-6 \mathrm{E}$ probably reflect depth variations to the top of the Paleozoic carbonates. The lows on both ends of the telluric traverse indicate the electrically conductive Muddy Creek Formation. AMT station LVW1 (see appendix) shows that the corresponding apparent resistivities are low, from 5 to $60 \mathrm{ohm}-\mathrm{m}$, which correlates very well with the calculated resistivities derived from the telluric traverse data.

Figure 6 is the location map for the Moapa telluric traverse at the east end of Arrow Canyon. Electrode position 0 was selected far enough to the west to be on what was expected to be high resistivity carbonates. Carbonates outcropped both to the north and south within $100 \mathrm{~m}$ of this position. The telluric traverse data (figure 7) show lows to the east and surprisingly to the west as well. The Moapa AMT sounding on dipole 0-1W (figure 8) has apparent resistivities of $400-1000 \mathrm{ohm}-\mathrm{m}$ for the 25 to $7.5 \mathrm{~Hz}$ frequency range. These values are lower than would be expected for an unfractured carbonate sequence. The low resistivities imply that significant fracturing has occurred in the Paleozoic carbonate and that it extends to some depth. 
Figure 9 shows the location of the $3.5 \mathrm{~km}$ long Cow Camp telluric traverse across a graben from the Black Hills to the Desert Range. The plot of the telluric traverse data relative voltages taken with $500 \mathrm{~m}$-1ong dipoles (figure 10) shows the high resistivities of the carbonate rocks on either end of the line. Figure 11 shows the Cow Camp AMT sounding made with dipole 0-1W. The resistivities in the Black Hills are about $13,000 \mathrm{ohm}-\mathrm{m}$ with the central part of the graben about $200 \mathrm{ohm}-\mathrm{m}$. No evidence of subsurface topography in the high resistivity carbonate rocks in the central portion of the graben can be seen, implying about $1 \mathrm{~km}$ of valley fill or that the basement resistivity in the central portion of the graben is low.

Figure 12 shows a detailed map of the Corn Creek telluric traverses. Figure 13 is a plot of telluric traverse no. 1, which crosses normal to the surface expression of the spring mounds at Corn Creek Springs. These data show that the spring mounds (dipoles $1 E$ to $3 E$ ) are an area of lower resistivity. The lowest resistivity, however, is the last dipole position $(4 \mathrm{E}-5 \mathrm{E})$ which probably reflects in part the exposed finer grained and more conductive Las Vegas Valley lake bed sediments. Figure 14 is the AMT sounding made on dipole $0-1 \mathrm{~W}$ to give apparent resistivities. Figure 15 is a plot of the telluric data acquired along the Mormon Well Road. Telluric response on the $500 \mathrm{~m}-1$ ong dipoles along this $4.5 \mathrm{~km}$ traverse is relatively flat with the low at dipole 1-2 corresponding to the mounds at Corn Creek Springs. Figure 16 is a plot of the response from the $500 \mathrm{~m}$-1ong dipoles starting at the east end of Corn Creek Springs telluric traverse no. 2 (electrode position no. 9) and going up the pediment to the mouth of First Canyon. The range-front fault is represented by the single point low (dipole 5-6). The high at dipole 6-7 is on the carbonates of the Sheep Range reflecting the higher resistivities of the carbonate rocks. The broad low from dipole 1-4, which is slightly more pronounced at the lower frequencies, probably reflects increased porosity in the carbonates.

To get an approximation of the geoelectric section, several AMT stations were inverted and then plotted on a southwest to northeast line (figure 17). The low resistivities to the southwest (AMT station LVW13) reflect the finergrained more-conductive Las Vegas Va1ley lake beds. AMT station LVW12 is the closest to the spring mounds at Corn Creek Springs and shows a low resistivity zone about $150 \mathrm{~m}$ below the surface. Stations LVW10 and LVW9 also show a low resistivity zone, but it is somewhat deeper, $450 \mathrm{~m}$ and $600 \mathrm{~m}$ respectively. AMT station LVW8 is on the edge of the paleozoic carbonates and shows relatively high resistivities. Between stations LVW9 and LVW8 there is a gradient which probably reflects the range front fault of the Sheep Range. A near surface higher resistivity tongue extends from station LVW8 on the northeast to station LVW10 to the southwest. This higher resistivity zone is probably an expression of the alluvial fan material on the west slope of the Sheep Range. 


\section{REFERENCES}

Beyer, J. H., 1977, Telluric and DC resistivity techniques applied to the geophysical investigation of Basin and Range geothermal systems: University of California, Lawrence Berkeley Laboratory Report LBL-6325.

Bostick, F. X., Jr., 1977, A simple and almost exact method of MT analysis: Geothermal Workshop Report, University of Utah, USGS Contract 14-08-00016-359, p. 175-177.

Hoover, D. B., Frischknecht, F. C., and Tippens, C. L., 1976, Audiomagnetotelluric soundings as a reconnaissance exploration technique in Long Valley, California: Journal of Geophysical Research, v. 81, p. 801809 .

Hoover, D. B., and Long, C. L., 1976, Audio-magnetotelluric methods in reconnaissance geothermal exploration: Proceedings, 2d U.N. Symposium, Developmental Geothermal Resources, p. 1059-1064.

Hoover, D. B., Long, C. L., and Senterfit, R. M., 1978, Some results from audio-magnetotelluric investigations in geothermal areas: Geophysics, v. 43 , p. 1501-1514.

Keller, G. V., and Frischknecht, F. C., 1966, Electrical methods in geophysical prospecting: New York Pergamon Press, p. 197-250.

Leonardon, E. G., 1928, Source observations upon telluric currents and their applications to electrical prospecting: Terr. Mag., v. 33, p. 91-94.

Strangway, D. W., Swift, C. M., Jr., and Holmer, R. C., 1973, The application of audio-frequency magnetotelluric (AMT) to mineral exploration: Geophysics, v. 38, p. 1159-1175. 
Figure 1. General overview of telluric traverse locations plotted on the USGS Las Vegas AMS $1: 250,000$ scale map.

Figure 2. General overview of AMT station locations plotted on the USGS Las Vegas AMS $1: 250,000$ scale map.

Figure 3. Location map of the Coyote telluric traverse plotted on the 7.5minute Wildcat Wash SW, Nevada quadrangle.

Figure 4. Coyote telluric traverse. Voltages are logarithmic with station $6 \mathrm{~W}-5 \mathrm{~W}$ assigned a value of 1 with data offset one decade. Dipoles are 125 meters long.

Figure 5. AMT sounding made on the $125 \mathrm{~m}-1$ ong dipole $0-1 \mathrm{~W}$ of the Coyote telluric traverse to reference apparent resistivities to the relative telluric ratios.

Figure 6. Location map of the Moapa Telluric Traverse plotted on the 15minute Arrow Canyon Quadrangle, Nevada.

Figure 7. Moapa telluric traverse. Telluric voltages are plotted on a $10 \mathrm{~g}$ scale with the station $3 \mathrm{~W}-2 \mathrm{~W}$ assigned a value of one and offset 1 decade. Dipoles are 250 meters long.

Figure 8. AMT sounding made on the $250 \mathrm{~m}-1$ ong dipole $0-1 \mathrm{~W}$ of the Moapa telluric traverse to reference apparent resistivities to the relative telluric ratios.

Figure 9. Location map of the Cow Camp telluric traverse plotted on the Black Hills SW, Nevada and Black Hills, Nevada 7.5 minute quadrangles.

Figure 10. Cow Camp telluric traverse. Relative telluric voltage scale is plotted on a log scale with the station 1-0 assigned a value of 1 and offset one decade. Dipoles are 500 meters long.

Figure 11. AMT sounding made on the 0-1 dipole of the Cow Camp telluric traverse to reference apparent resistivities to the relative telluric ratios.

Figure 12. Corn Creek telluric traverses plotted on the Corn Creek Springs, Nevada 7.5-minute quadrangle.

Figure 13. Corn Creek telluric line no. 1. Relative telluric voltages are plotted on a log scale with the station $3 W-2 W$ assigned a value of 1. Each of the three frequencies are offset one decade. Dipoles are 250 meters 1ong.

Figure 14. AMT sounding made on the $0-1 \mathrm{~W}$ dipole of the Corn Creek Springs telluric traverse to reference apparent resistivities to the relative telluric ratios. 
Figure 15. Corn Creek telluric line no. 2. Relative telluric voltages are plotted on a log scale with the station $0-1$ assigned a value of 1 with frequencies offset one decade. Self-potential data were recorded along this line and plotted in millivolts. Dipoles are 500 meters long.

Figure 16. Corn Creek telluric line no. 3. Telluric voltages are plotted on a $\log$ scale with the station $0-1$ assigned a value of 1 and an arbitrary offset of 1 decade. Dipoles are 500 meters long.

Figure 17. Electrical cross-section of inverted AMT stations 8, 9, 10, 12, \& 13. These stations are normalized to a line that strikes approximately SW to NE. Station 13 is on conductive lake beds and station 8 is on the resistive carbonates at the foot of the Sheep Range. Exact locations of the AMT stations are shown on figure 2 . 


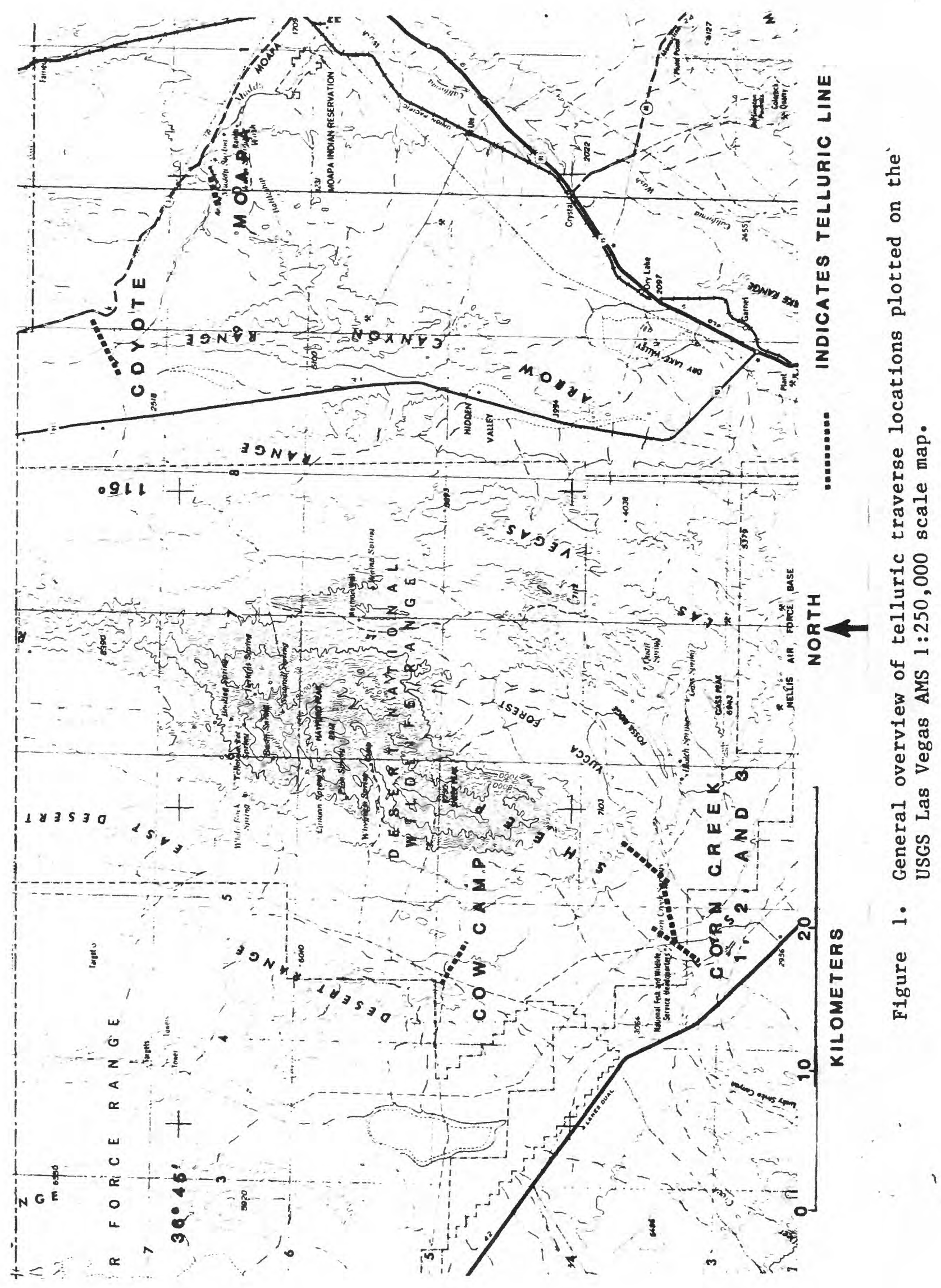




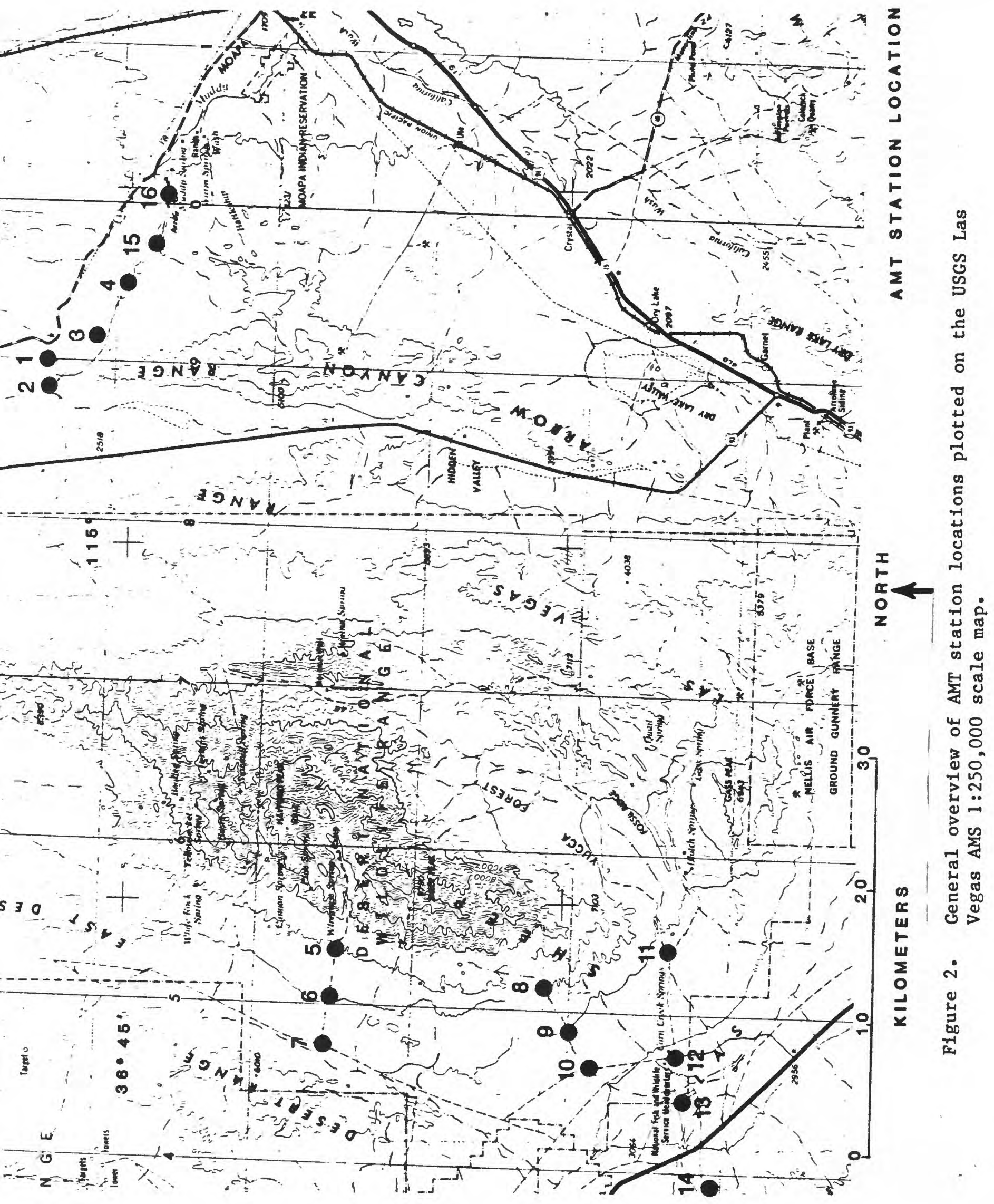




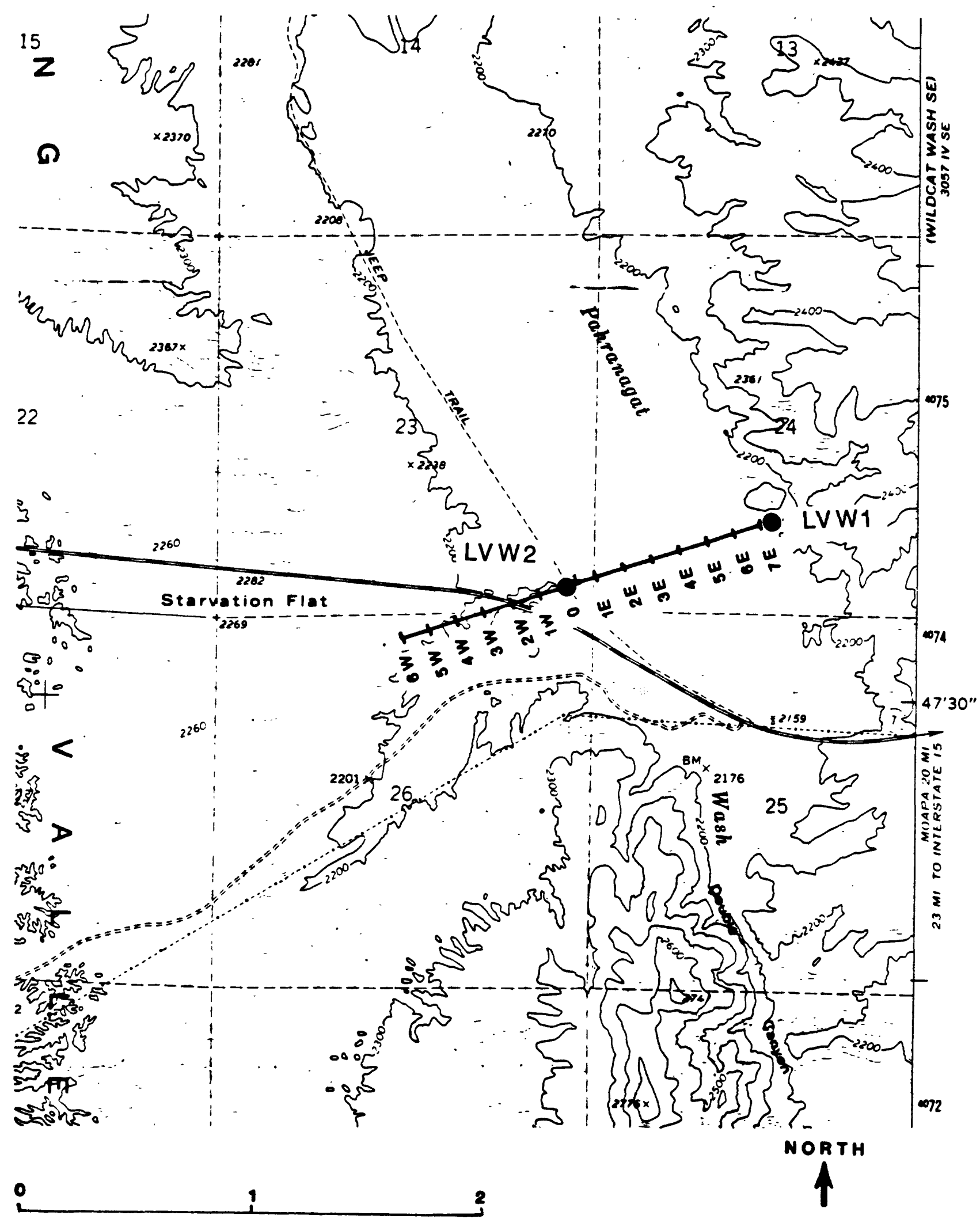

KILOMETER 8

Figure 3. Location map of the Coyote telluric traverse plotted on the 7.5minute Wildcat Wash SW, Nevada quadrangle. 
COYOTE TELLURIC LINE

\section{LINE STRIKES N72E}

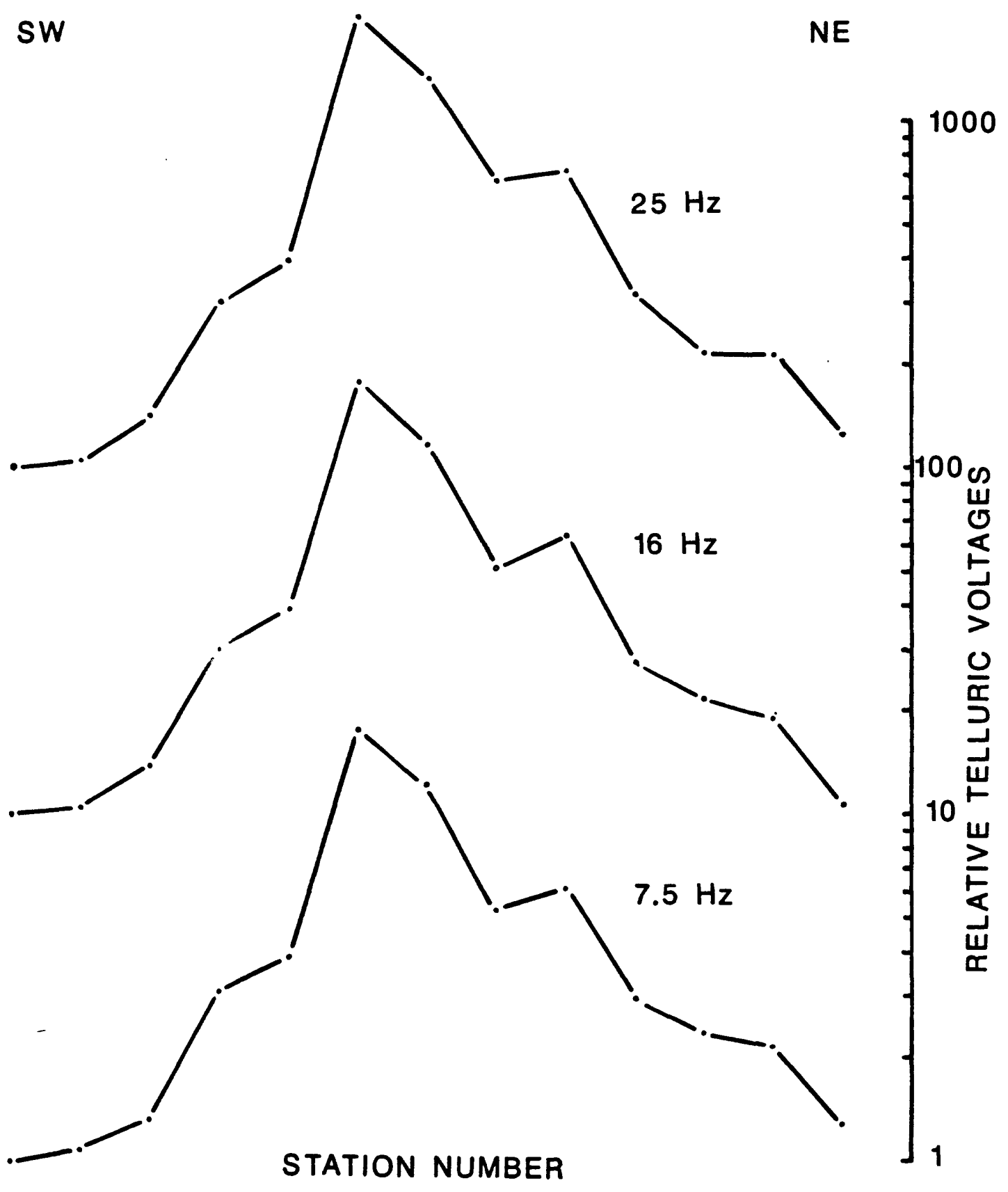

$6 W \quad 5 W \quad 4 W \quad 3 W \quad 2 W \quad 1 W \quad 0 \quad 1 E$ 2E $3 E$ 4E $5 E$ 6E

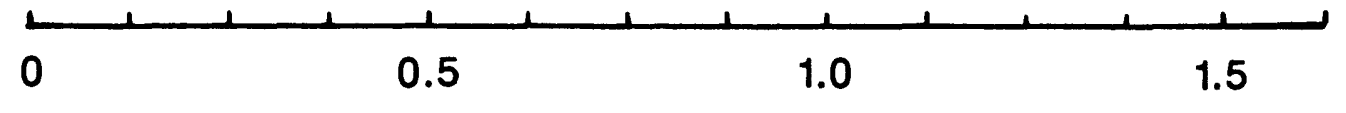

\section{DISTANCE IN KILOMETERS}

Figure 4. Coyote telluric traverse. Voltages are logarithmic with station $6 \mathrm{~W}-5 \mathrm{~W}$ assigned a value of 1 with data offset one decade. Dipoles are 125 meters long. 


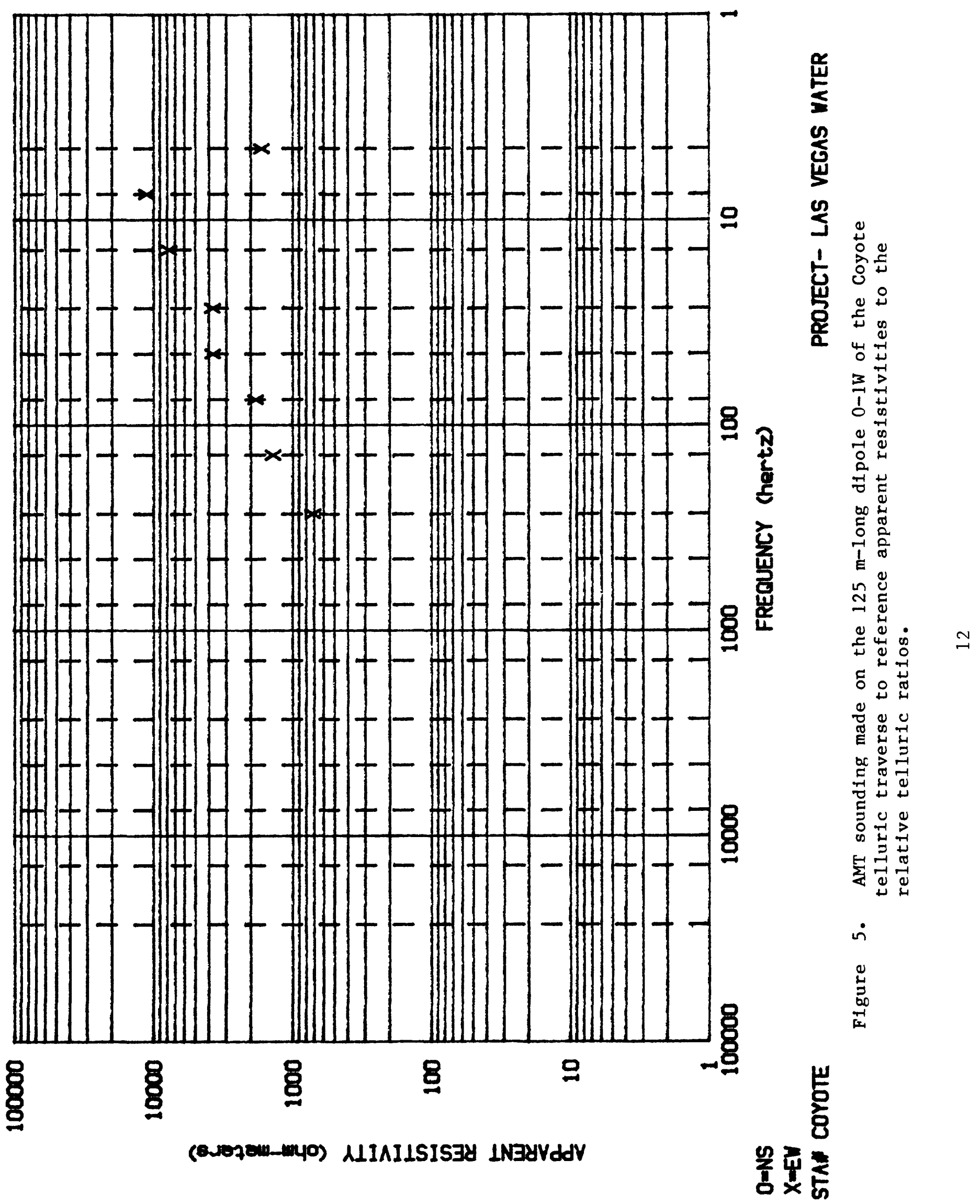


ARROW CANYON QUADRANGLE

NEVADA-CLARK CO.

15 MINUTE SERIES (TOPOORAPHIC)

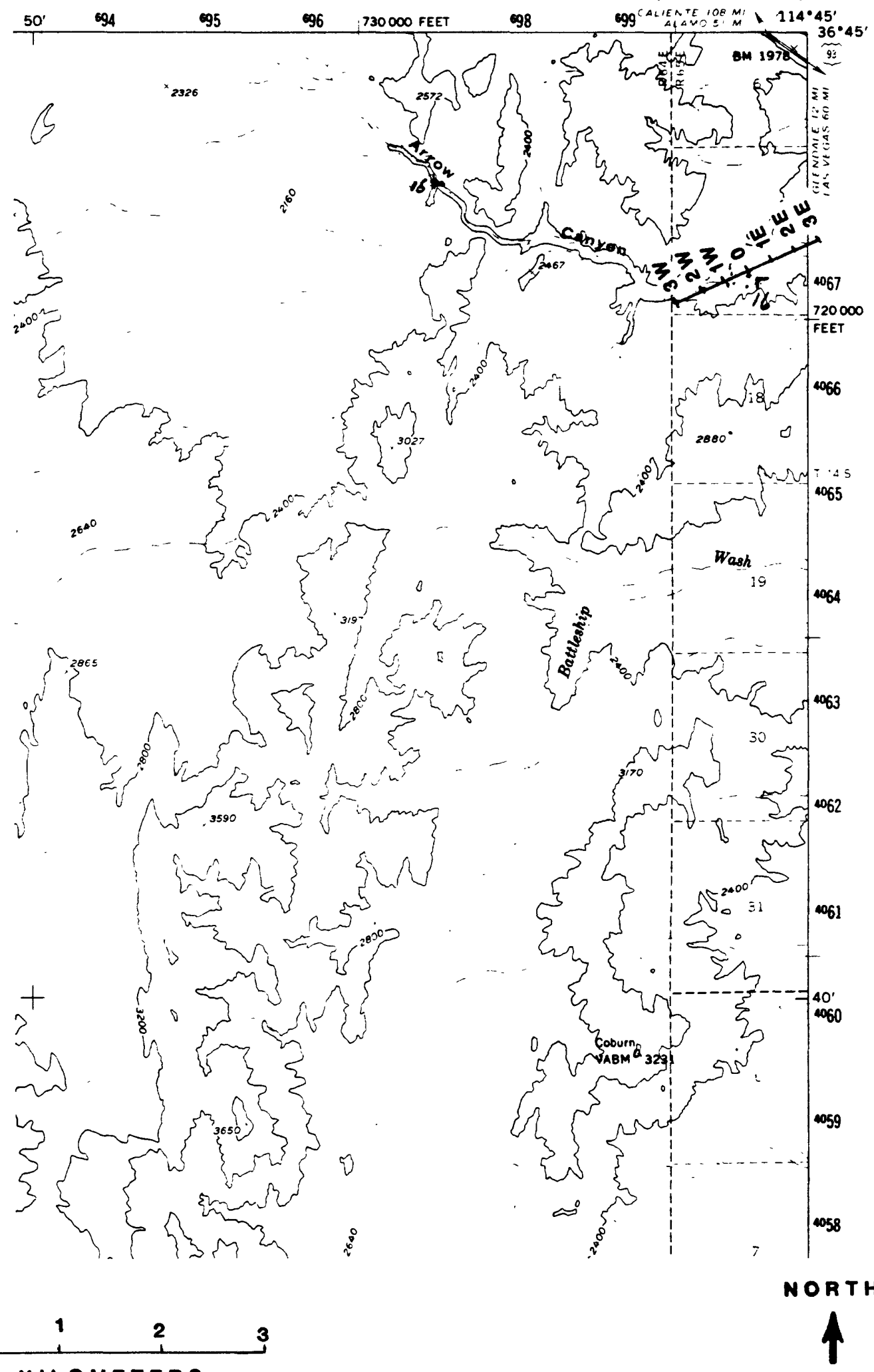

KILOMETERS

Figure 6. Location map of the Moapa Telluric Traverse plotted on the 15minute Arrow Canyon Ouadrangle, Nevada. 


\section{MOAPA TELLURIC LINE \\ LINE STRIKES N66E}

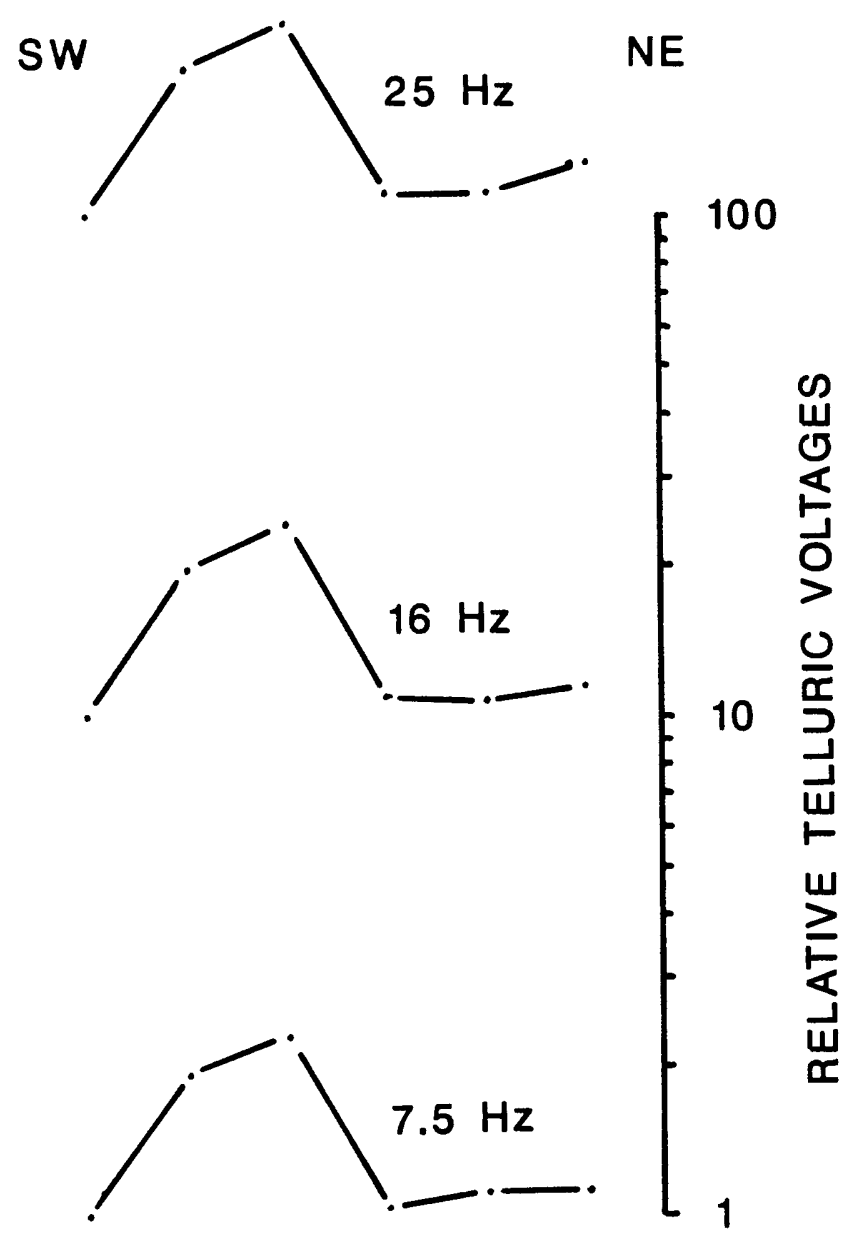

STATION NUMBER

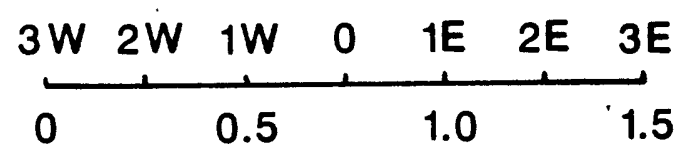

DISTANCE IN KILOMETERS

Figure 7. Moapa telluric traverse. Telluric voltages are plotted on a $10 \mathrm{~g}$ scale with the station $3 W-2 W$ assigned a value of one and offset 1 decade. Dipoles are 250 meters long. 


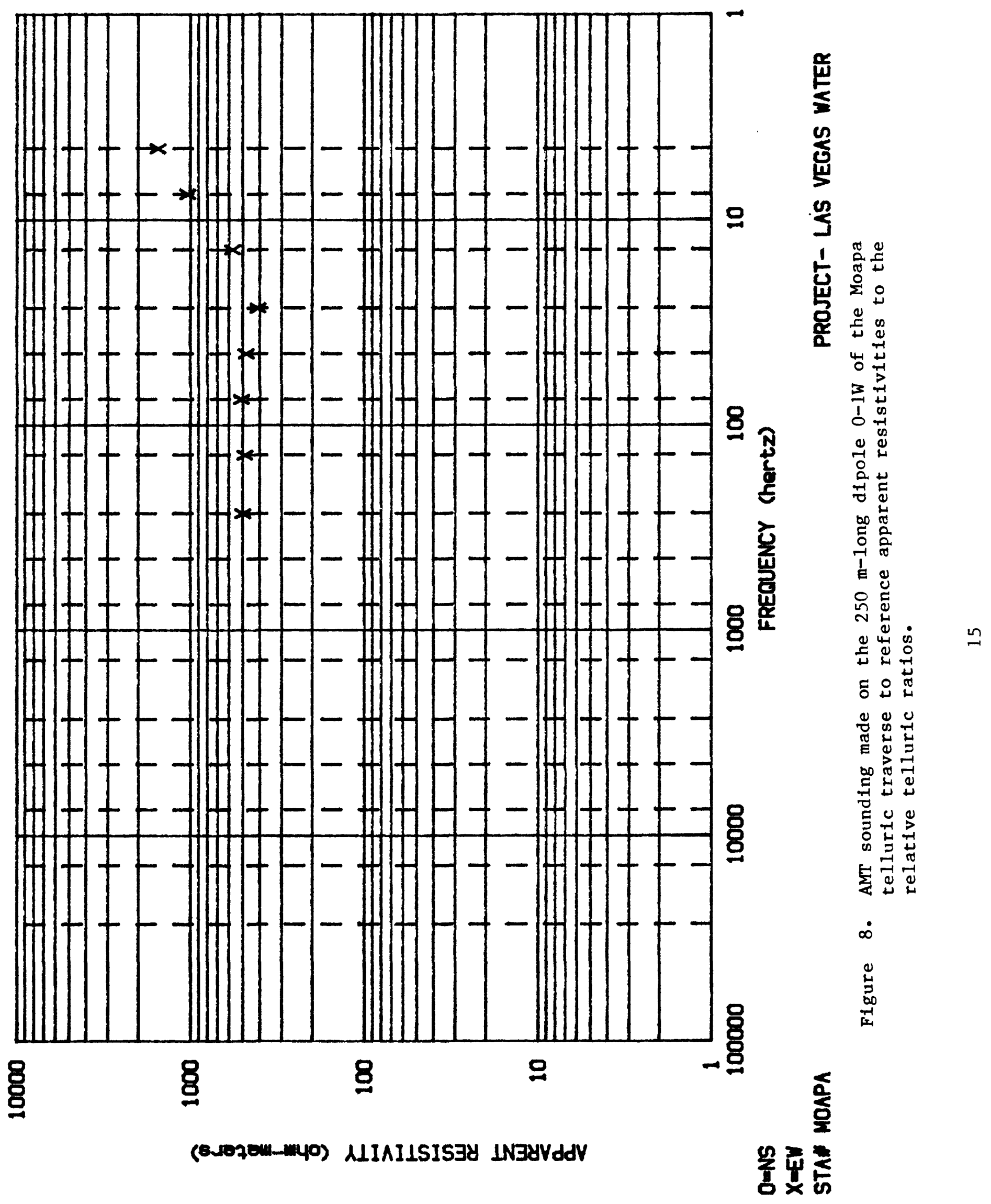




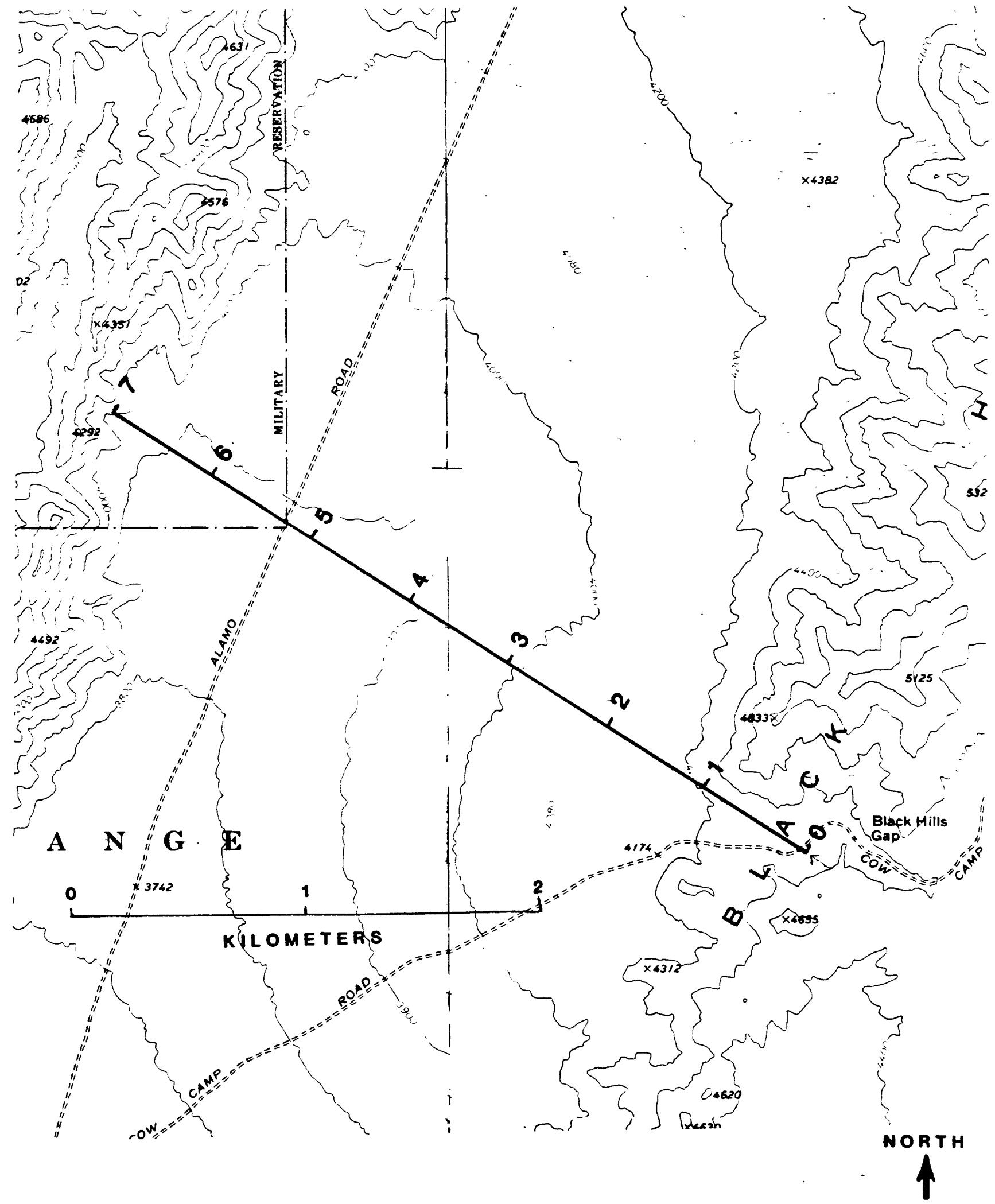

Figure 9. Location map of the Cow Camp telluric traverse plotted on the Black Hills SW, Nevada and Black Hills, Nevada 7.5 minute quadrangles. 


\section{COW CAMP TELLURIC LINE \\ LINE STRIKES N59W}

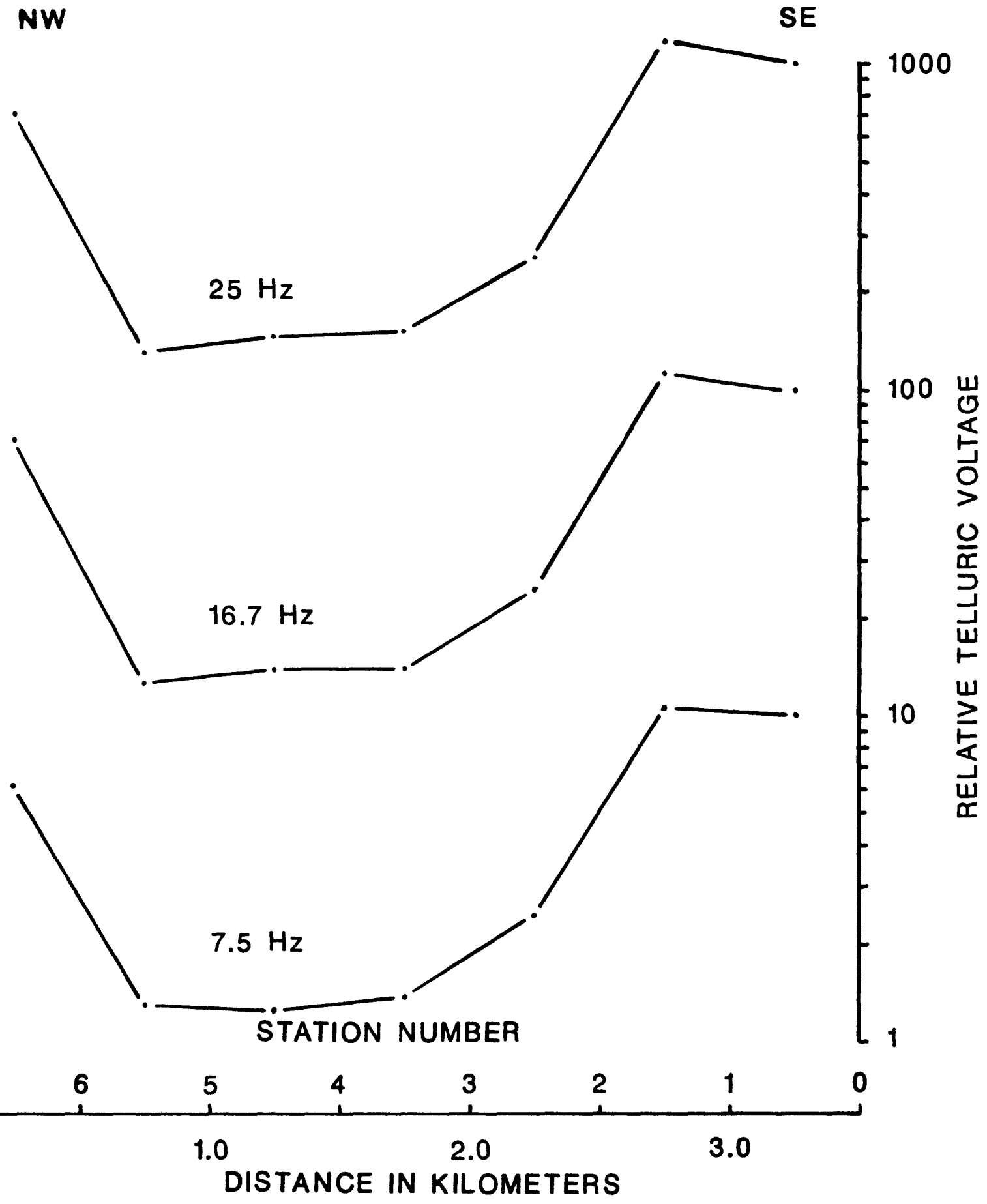

Figure 10. Cow Camp telluric traverse. Relative telluric voltage scale is plotted on a log scale with the station 1-0 assigned a value of 1 and offset one decade. Dipoles are 500 meters long. 


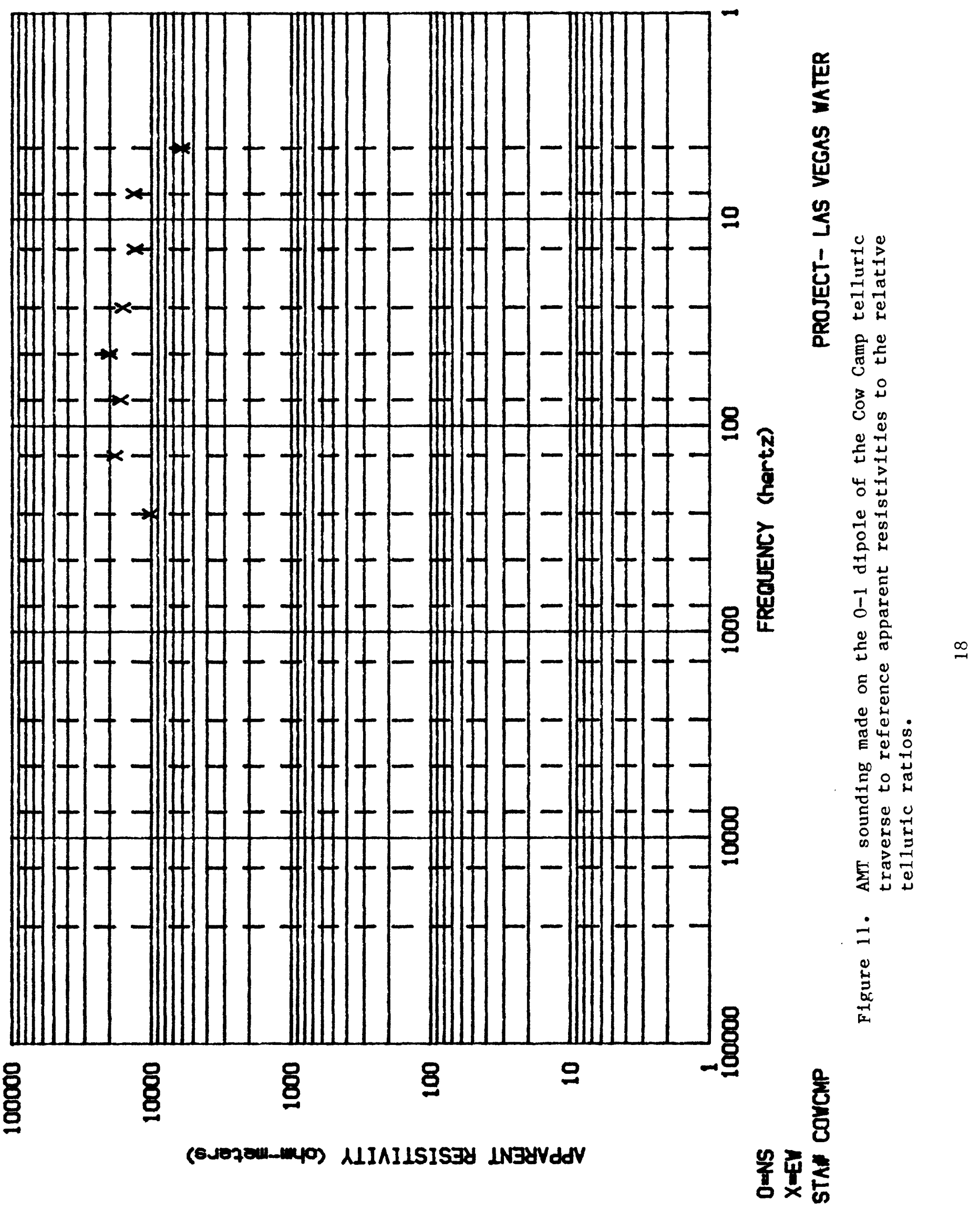




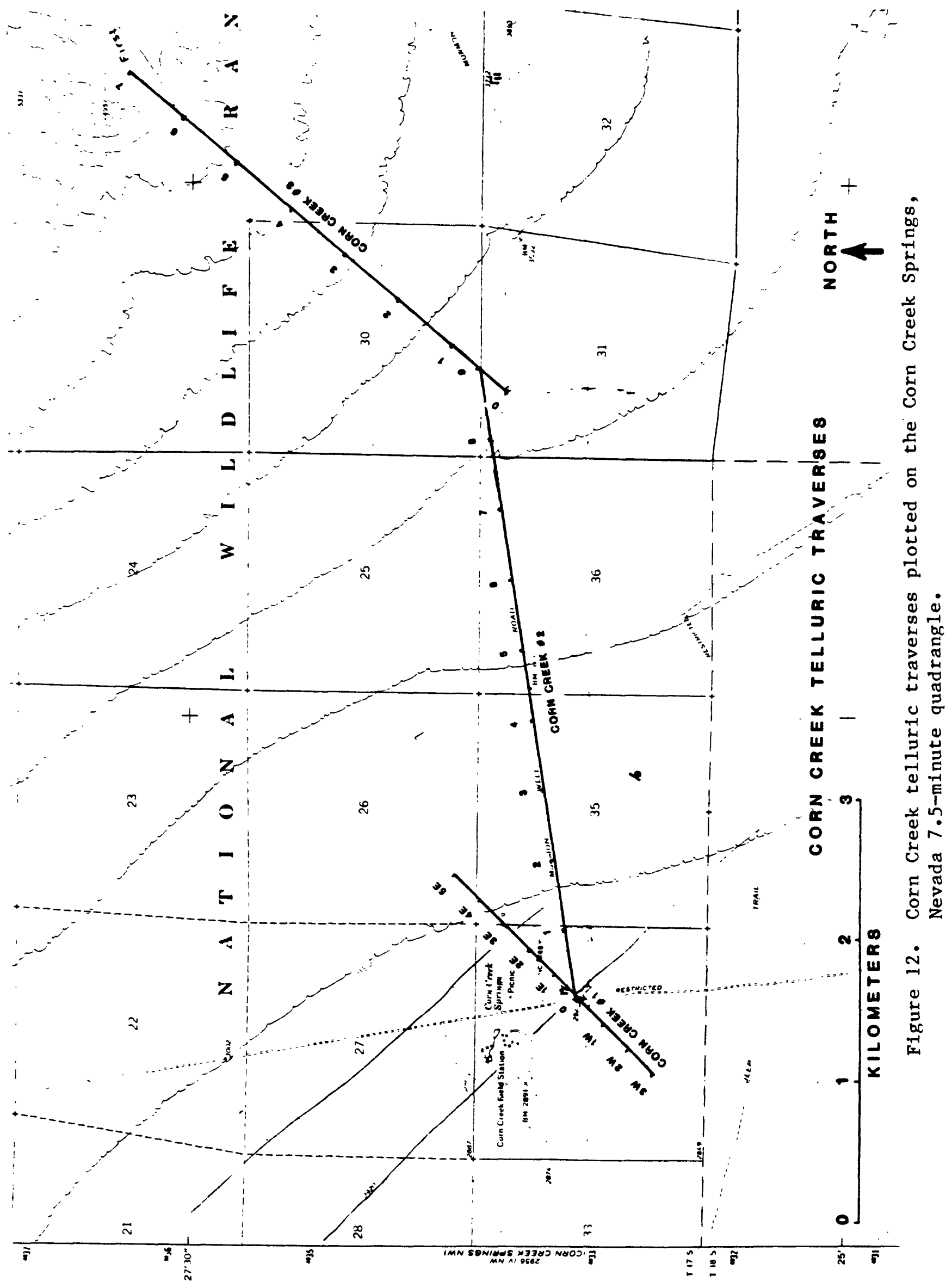

$\stackrel{\sigma}{\sim}$ 


\section{CORN CREEK TELLURIC LINE \#1 LINE STRIKES N45E}

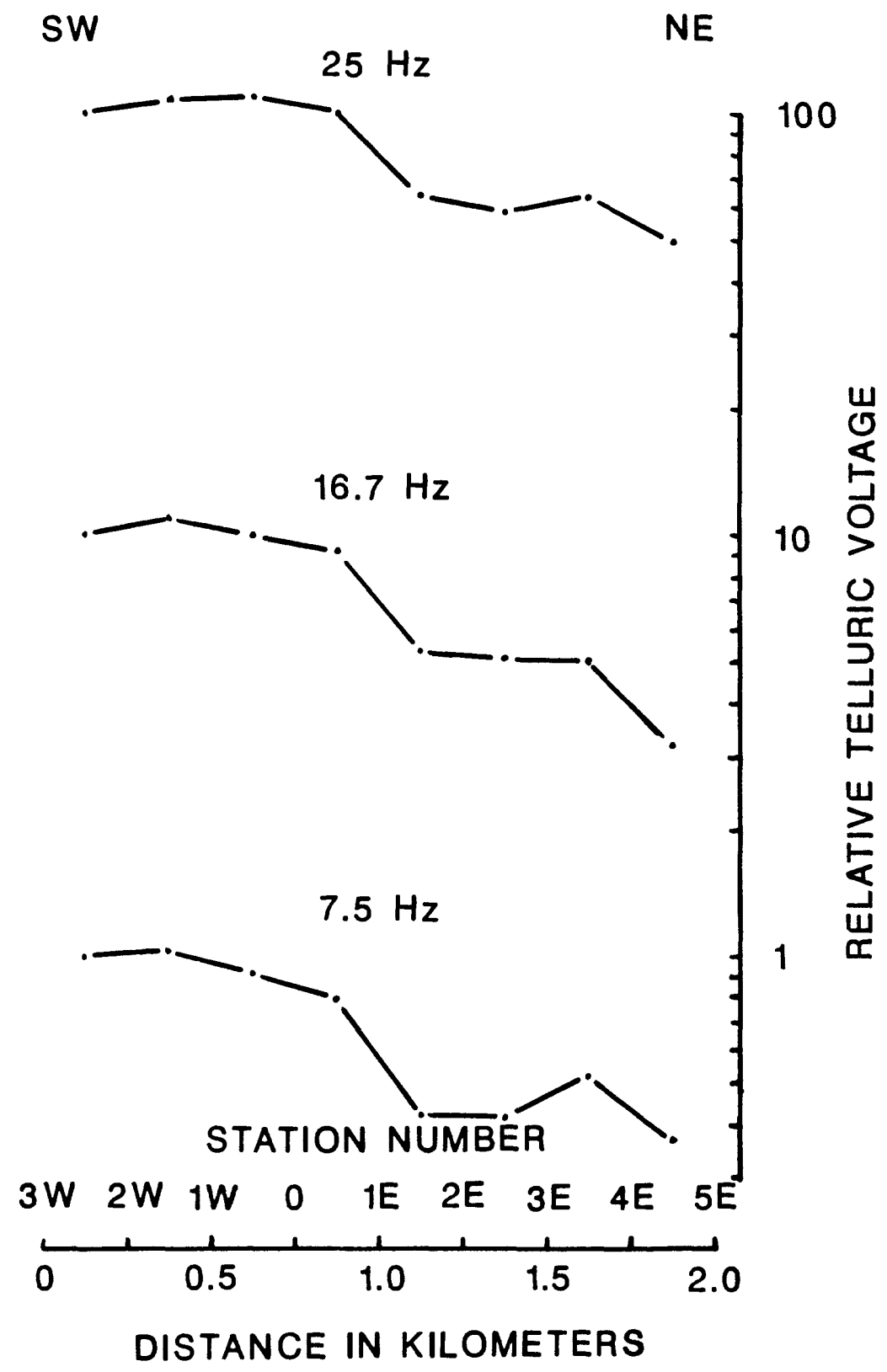

Figure 13. Corn Creek telluric line no. 1. Relative telluric voltages are plotted on a log scale with the station $3 \mathrm{~W}-2 \mathrm{~W}$ assigned a value of 1. Each of the three frequencies are offset one decade. Dipoles are 250 meters long. 


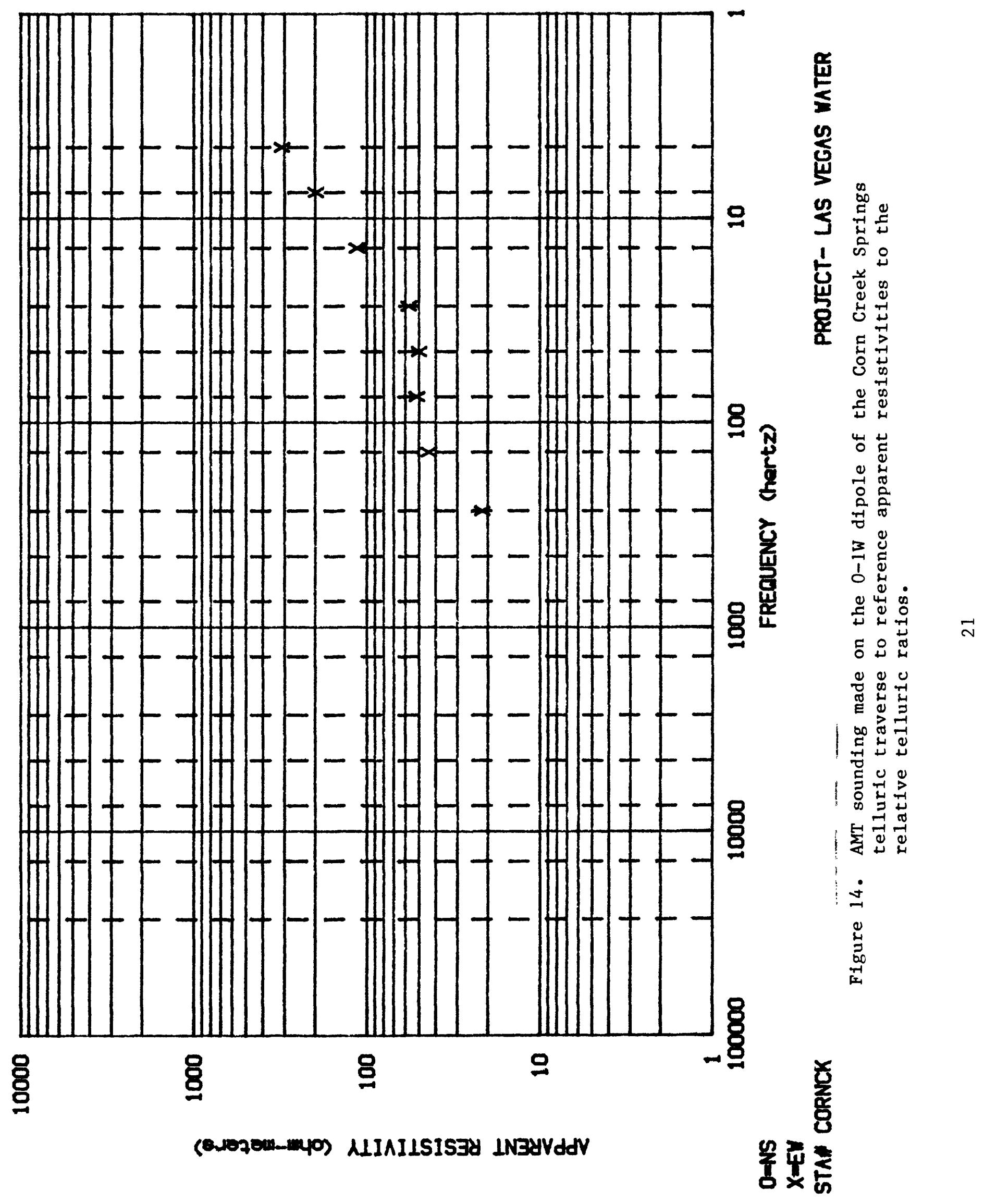




\section{CORN CREEK TELLURIC LINE $* 2$ LINE STRIKES NBIE}

SW

NE

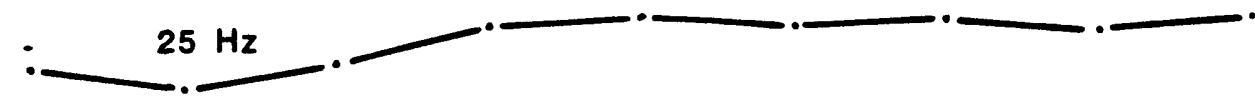

$16.7 \mathrm{~Hz}$
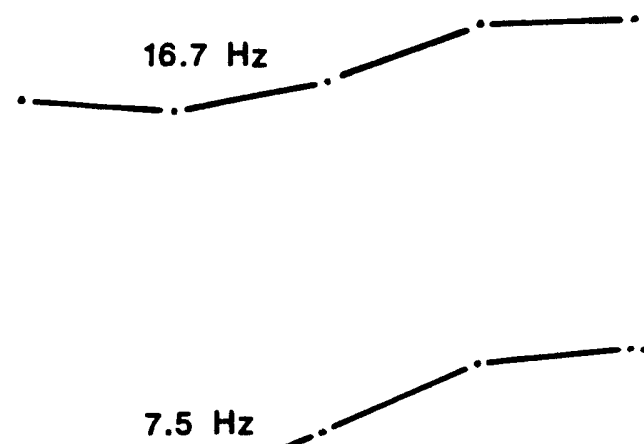

$7.5 \mathrm{~Hz}$
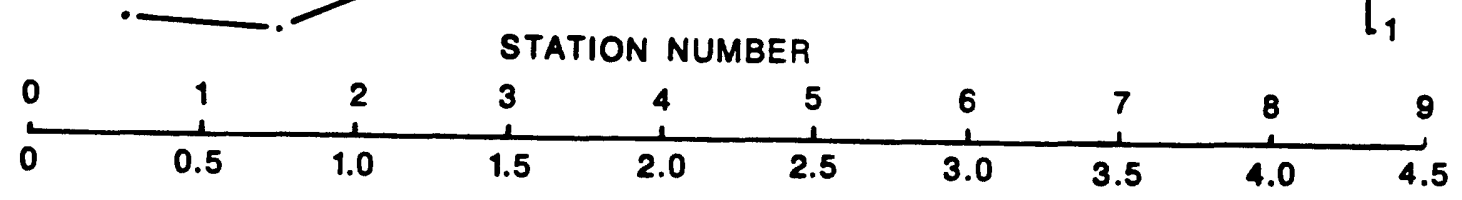

DISTANCE IN KILOMETERS

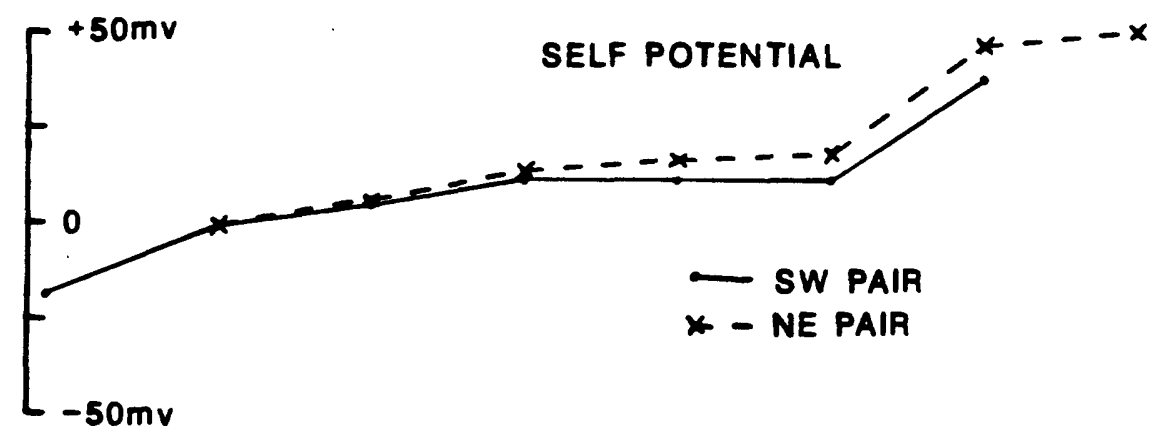

Figure 15. Corn Creek telluric line no. 2. Relative telluric voltages are plotted on a log scale with the station $0-1$ assigned a value of 1 with frequencies of fset one decade. Self-potential data were recorded along this line and plotted in millivolts. Dipoles are 500 meters long. 


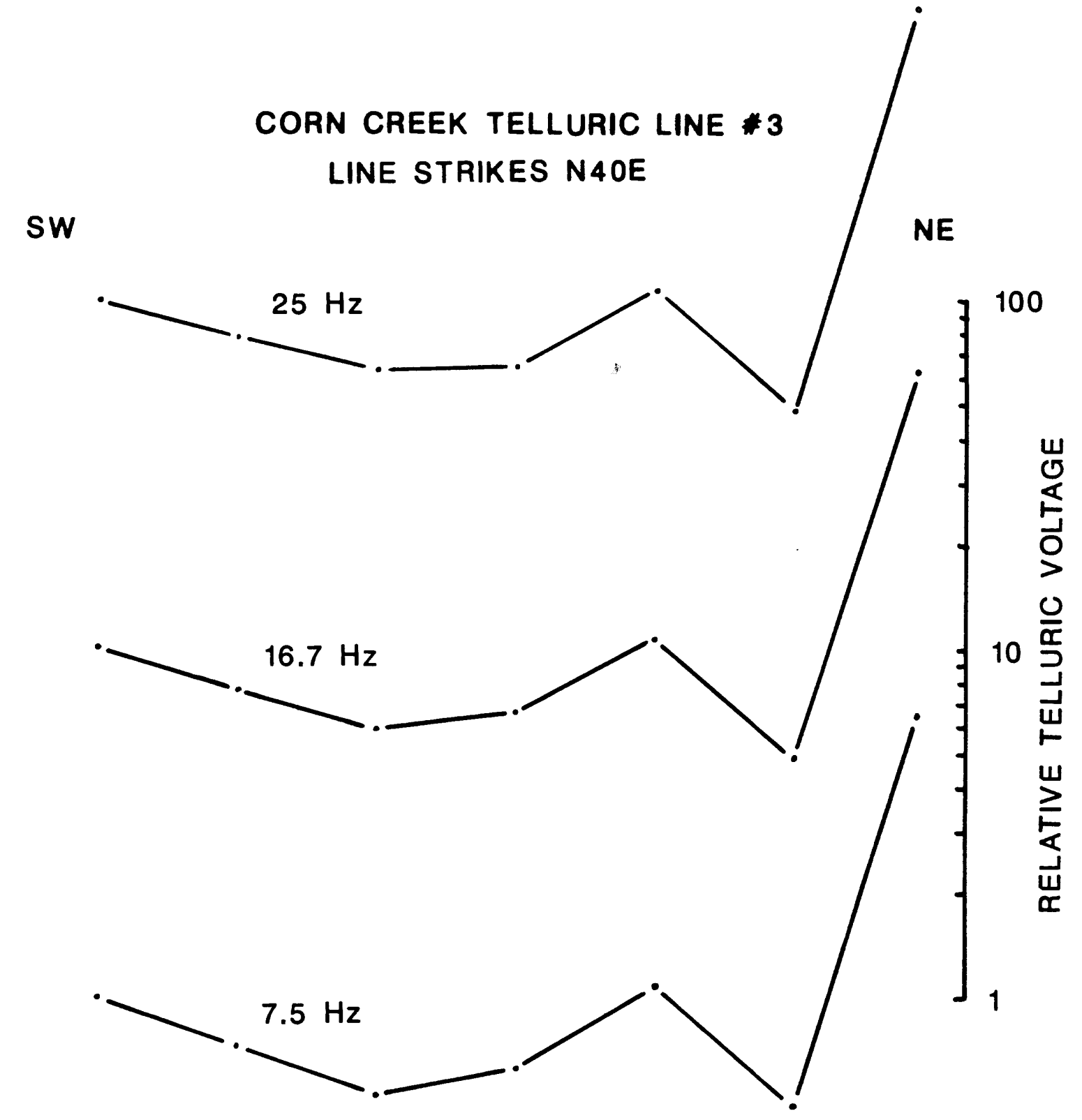

STATION NUMBER

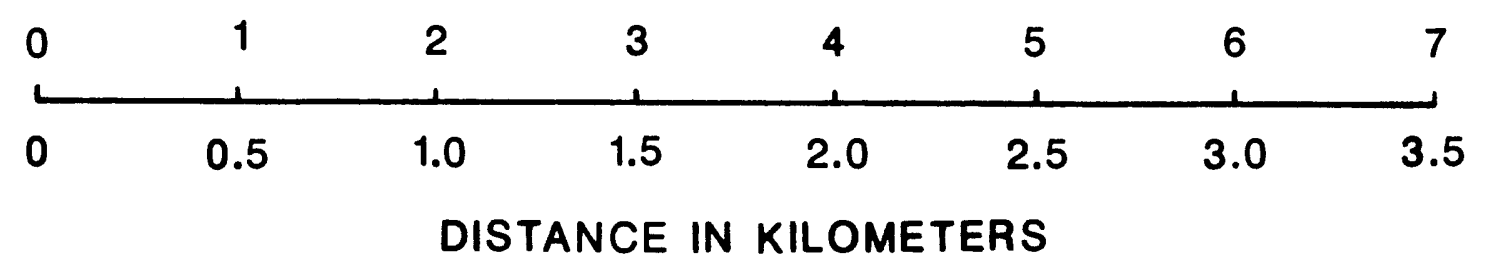

Figure 16. Corn Creek telluric line no. 3. Telluric voltages are plotted on a $\log$ scale with the station $0-1$ assigned a value of 1 and an arbitrary offset of 1 decade. Dipoles are 500 meters long. 


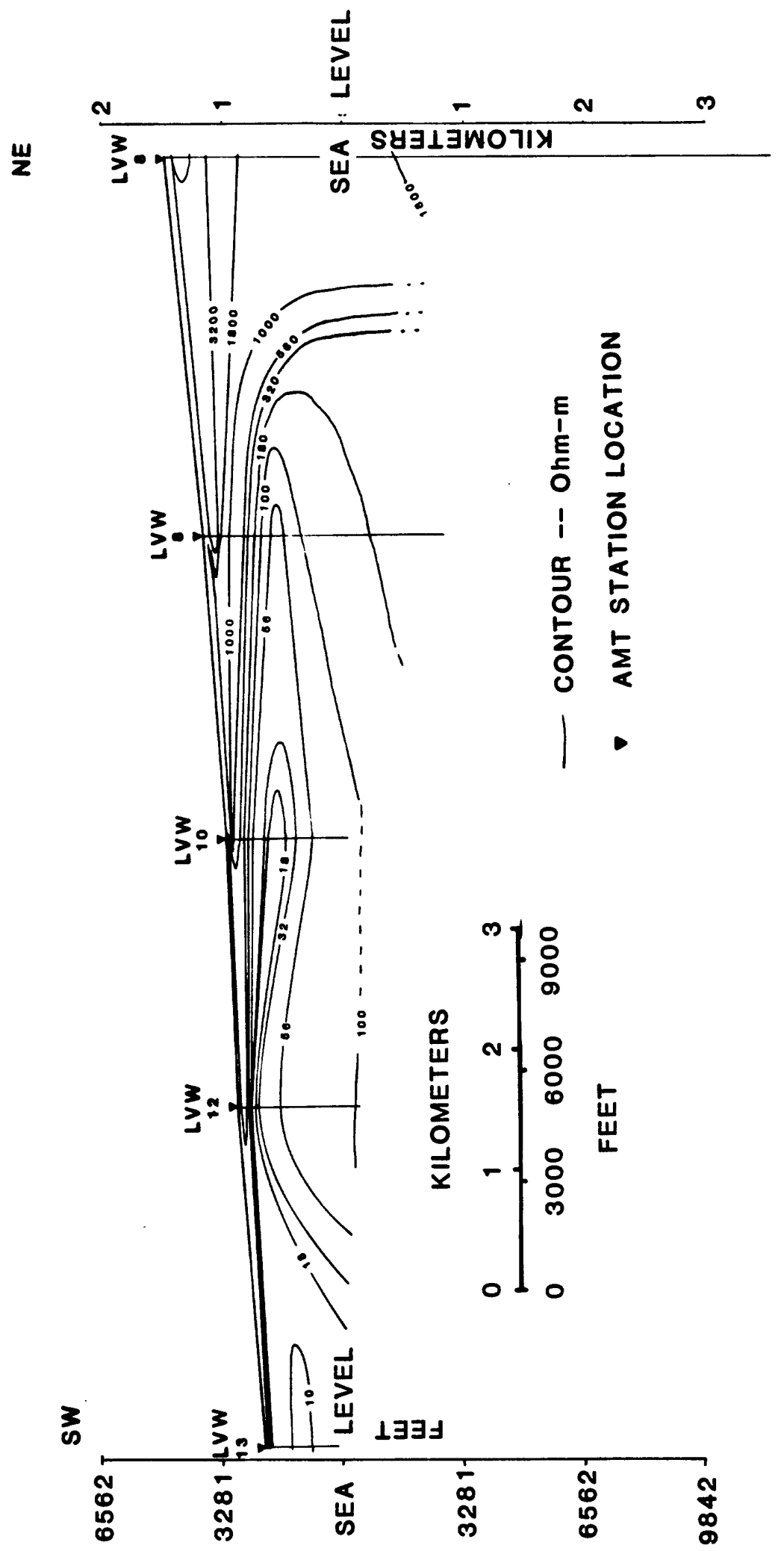

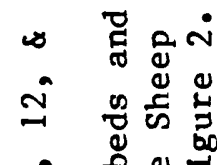

○ी

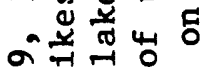

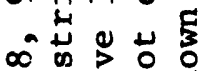

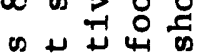

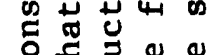

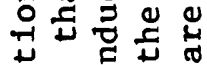

ฮै ข

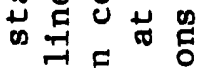

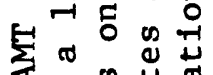

운휴

षै 5

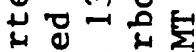

o 5 政

거엉

至品步

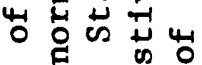

둥

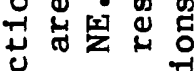

\& क 00

क品读

की 3

की 步 5

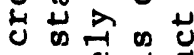

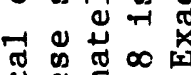

U⿺

出它芒号

U

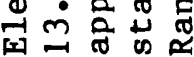

$\stackrel{+}{\sim}$

$\underset{7}{2}$ 
APPENDIX 1 


\begin{tabular}{|c|c|c|c|c|c|c|}
\hline \multirow{2}{*}{$\begin{array}{c}\begin{array}{c}\text { Station } \\
\text { No. }\end{array} \\
\end{array}$} & \multicolumn{3}{|c|}{ Ratio/Std. deviation } & \multicolumn{3}{|c|}{ Relative voltage } \\
\hline & $25 \mathrm{~Hz}$ & $16.7 \mathrm{~Hz}$ & $7.5 \mathrm{~Hz}$ & $25 \mathrm{~Hz}$ & $16.7 \mathrm{~Hz}$ & $7.5 \mathrm{~Hz}$ \\
\hline & & & & 1 & 1 & 1 \\
\hline $5 \mathrm{~W}$ & $1.05 / .01$ & $1.04 / .01$ & $1.09 / .02$ & 1.05 & 1.037 & 100 \\
\hline $4 \mathrm{~W}$ & $1.35 / .02$ & $1.31 / .01$ & $1.21 / .03$ & & & \\
\hline $3 \mathrm{~W}$ & $2.14 / .06$ & $2.22 / .11$ & $2.35 / .26$ & 1.41 & 1.36 & 1.32 \\
\hline $2 \mathrm{~W}$ & $1.30 / 01$ & $130 / 01$ & $1.25 / 01$ & 3.026 & 3.01 & 3.10 \\
\hline & & & & 3.93 & 3.91 & 3.88 \\
\hline $1 \mathrm{~W}$ & $5.10 / .07$ & $4.52 / .09$ & $4.52 / .12$ & 20.00 & 17.69 & 17.54 \\
\hline 0 & $.66 / .01$ & $.66 / .16$ & $.69 / .01$ & 13.20 & 11.67 & 12.10 \\
\hline $1 E$ & $.47 / .01$ & $.44 / .01$ & $.44 / .01$ & 6.17 & 5.16 & 5.29 \\
\hline $2 \mathrm{E}$ & $1.16 / .01$ & $1.17 / .01$ & $1.16 / .01$ & 7.16 & 6.04 & 6.14 \\
\hline $3 E$ & $.44 / .01$ & $.46 / .03$ & $.48 / .01$ & 3.16 & 2.78 & 2.97 \\
\hline $4 \mathrm{E}$ & $.73 / .04$ & $.77 / .01$ & $.80 / .11$ & 2.32 & 2.14 & 2.36 \\
\hline $5 \mathrm{E}$ & $.92 / .01$ & $.90 / .01$ & $.907 / .05$ & 2.12 & 1.91 & 2.14 \\
\hline $6 \mathrm{E}$ & $.59 / .13$ & $.56 / .01$ & $.61 / .15$ & 1.25 & 1.07 & 1.29 \\
\hline
\end{tabular}


Moapa Telluric Line 1 250 m dipoles

\begin{tabular}{|c|c|c|c|c|c|c|}
\hline \multirow{2}{*}{$\begin{array}{c}\text { Station } \\
\text { No. } \\
\end{array}$} & \multicolumn{3}{|c|}{ Ratio/Std. deviation } & \multicolumn{3}{|c|}{ Relative voltage } \\
\hline & $25 \mathrm{~Hz}$ & $16.7 \mathrm{~Hz}$ & $7.5 \mathrm{~Hz}$ & $25 \mathrm{~Hz}$ & $16.7 \mathrm{~Hz}$ & $7.5 \mathrm{~Hz}$ \\
\hline \multicolumn{7}{|l|}{$3 W$} \\
\hline & & & & 1 & 1 & 1 \\
\hline $2 \mathrm{~W}$ & $1.99 / .04$ & $1.99 / .01$ & $1.92 / .04$ & & & \\
\hline $1 \mathrm{~W}$ & $.82 / .01$ & $.82 / .01$ & $.837 / .01$ & 1.37 & $1 \bullet>7$ & $1 \cdot 72$ \\
\hline & 20 & 22103 & ו 2271 & 2.44 & 2.43 & 2.29 \\
\hline & 2.00800 & $2 \cdot 2100$ & 20281000 & 1.11 & 1.10 & 1.03 \\
\hline $1 E$ & $1.01 / .01$ & $0.98 / .01$ & $1.079 / .01$ & & & \\
\hline & & & & 1.12 & 1.08 & 1.11 \\
\hline $2 E$ & $0.87 / .01$ & $0.94 / .01$ & $0.984 / .01$ & & & \\
\hline & & & & 1.28 & 1.15 & 1.13 \\
\hline
\end{tabular}




\begin{tabular}{|c|c|c|c|c|c|c|}
\hline \multirow{2}{*}{$\begin{array}{c}\text { Station } \\
\text { No. }\end{array}$} & \multicolumn{3}{|c|}{ Ratio/Std. deviation } & \multicolumn{3}{|c|}{ Relative voltage } \\
\hline & $-25 \mathrm{~Hz}$ & $16.7 \mathrm{~Hz}$ & $7.5 \mathrm{~Hz}$ & $25 \mathrm{~Hz}$ & $16.7 \mathrm{~Hz}$ & $7.5 \mathrm{~Hz}$ \\
\hline 0 & & & & 1 & 1 & 1 \\
\hline 1 & $1.20 / .01$ & $1.13 / .01$ & $1.06 / .05$ & 1.20 & 1.13 & 1.06 \\
\hline 2 & $.22 / .02$ & $.22 / .02$ & $.23 / .06$ & .26 & .24 & .24 \\
\hline 3 & $.59 / .02$ & $.57 / .04$ & $.56 / .05$ & .15 & .14 & .14 \\
\hline 4 & $.98 / .04$ & $.99 / .05$ & $.93 / .03$ & .15 & .14 & .13 \\
\hline 5 & $.89 / .06$ & $.91 / .07$ & $1.03 / .06$ & .13 & .13 & .13 \\
\hline 6 & $5.40 / .16$ & $5.56 / .06$ & $4.69 / .10$ & .71 & .70 & .61 \\
\hline
\end{tabular}




\begin{tabular}{|c|c|c|c|c|c|c|}
\hline \multirow{2}{*}{$\begin{array}{c}\begin{array}{c}\text { Station } \\
\text { No. }\end{array} \\
\end{array}$} & \multicolumn{3}{|c|}{ Ratio/Std. deviation } & \multicolumn{3}{|c|}{ Relative voltage } \\
\hline & $25 \mathrm{~Hz}$ & $16.7 \mathrm{~Hz}$ & $7.5 \mathrm{~Hz}$ & $25 \mathrm{~Hz}$ & $16.7 \mathrm{~Hz}$ & $7.5 \mathrm{~Hz}$ \\
\hline $3 \mathrm{~W}$ & & & & & & \\
\hline & & & & 1 & 1 & 1 \\
\hline $2 \mathrm{~W}$ & $1.09 / .06$ & $1.10 / .02$ & $1.03 / .10$ & 1.09 & 1.10 & 1.03 \\
\hline $1 \mathrm{~W}$ & $1.01 / .06$ & $.90 / .07$ & $.88 / .11$ & 1.10 & .99 & .91 \\
\hline 0 & $.91 / .08$ & $.93 / .04$ & $.87 / .13$ & 1.00 & .92 & .79 \\
\hline $1 \mathrm{E}$ & $.63 / .16$ & $.575 / .13$ & $.57 / .16$ & .64 & .53 & .4 \\
\hline $2 E$ & $.92 / .05$ & $.962 / .10$ & $.99 / .05$ & .59 & .51 & .443 \\
\hline $3 \mathrm{E}$ & $1.08 / .04$ & $.99 / .05$ & $1.17 / .11$ & .64 & .50 & .52 \\
\hline $4 \mathrm{E}$ & $.758 / .04$ & $.652 / .05$ & $.71 / .19$ & .48 & .33 & .37 \\
\hline
\end{tabular}




\section{Las Vegas Water}

Corn Creek Telluric Traverse \#3

$500 \mathrm{~m}$ dipoles

\begin{tabular}{|c|c|c|c|c|c|c|}
\hline \multirow{2}{*}{$\begin{array}{c}\text { Station } \\
\text { No. }\end{array}$} & \multicolumn{3}{|c|}{ Ratio/Std. deviation } & \multicolumn{3}{|c|}{ Relative voltage } \\
\hline & $-25 \mathrm{~Hz}$ & $16.7 \mathrm{~Hz}$ & $7.5 \mathrm{~Hz}$ & $25 \mathrm{~Hz}$ & $16.7 \mathrm{~Hz}$ & $7.5 \mathrm{~Hz}$ \\
\hline \multicolumn{7}{|l|}{0} \\
\hline & & & & 1 & 1 & 1 \\
\hline $1 \mathrm{NE}$ & $.80 / .01$ & $.77 / .01$ & $.74 / .11$ & & & \\
\hline $2 \mathrm{NE}$ & $.78 / .04$ & $.77 / .03$ & $.71 / .01$ & .80 & .77 & .74 \\
\hline & & & & .62 & .60 & .52 \\
\hline $3 \mathrm{NE}$ & $1.04 / .09$ & $1.11 / .03$ & $1.21 / .10$ & & & \\
\hline & & & & .65 & .66 & .63 \\
\hline $4 \mathrm{NE}$ & $1.64 / .06$ & $1.64 / .09$ & $1.69 / .05$ & 1.06 & 1.08 & 1.07 \\
\hline $5 \mathrm{NE}$ & $.45 / .34$ & $.45 / .16$ & $.46 / .36$ & .48 & .49 & .50 \\
\hline $6 \mathrm{NE}$ & $12.4 / .05$ & $12.7 / .03$ & $13.2 / .05$ & & & \\
\hline & & & & 5.91 & 6.16 & 6.55 \\
\hline
\end{tabular}


APPENDIX 2 


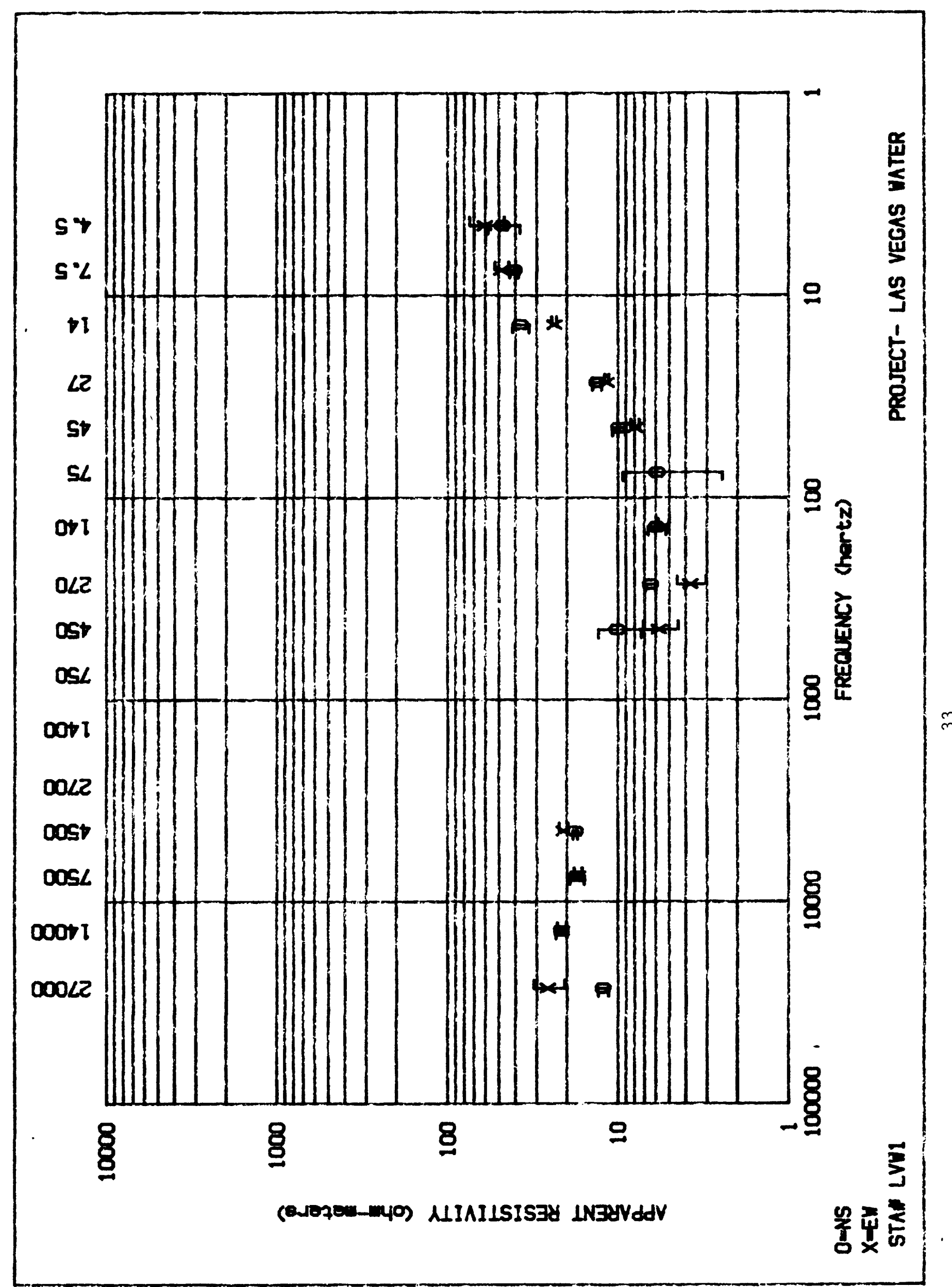




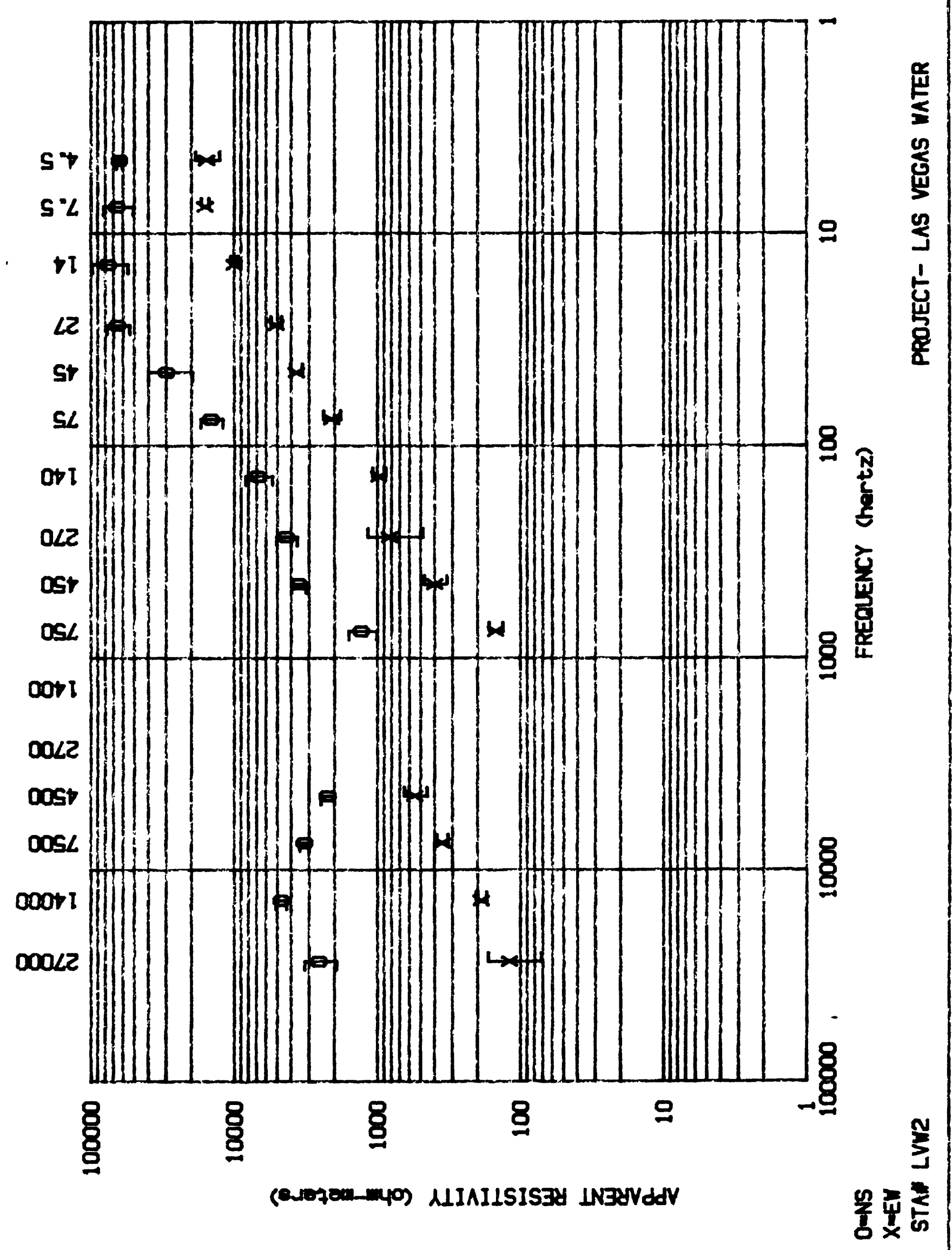




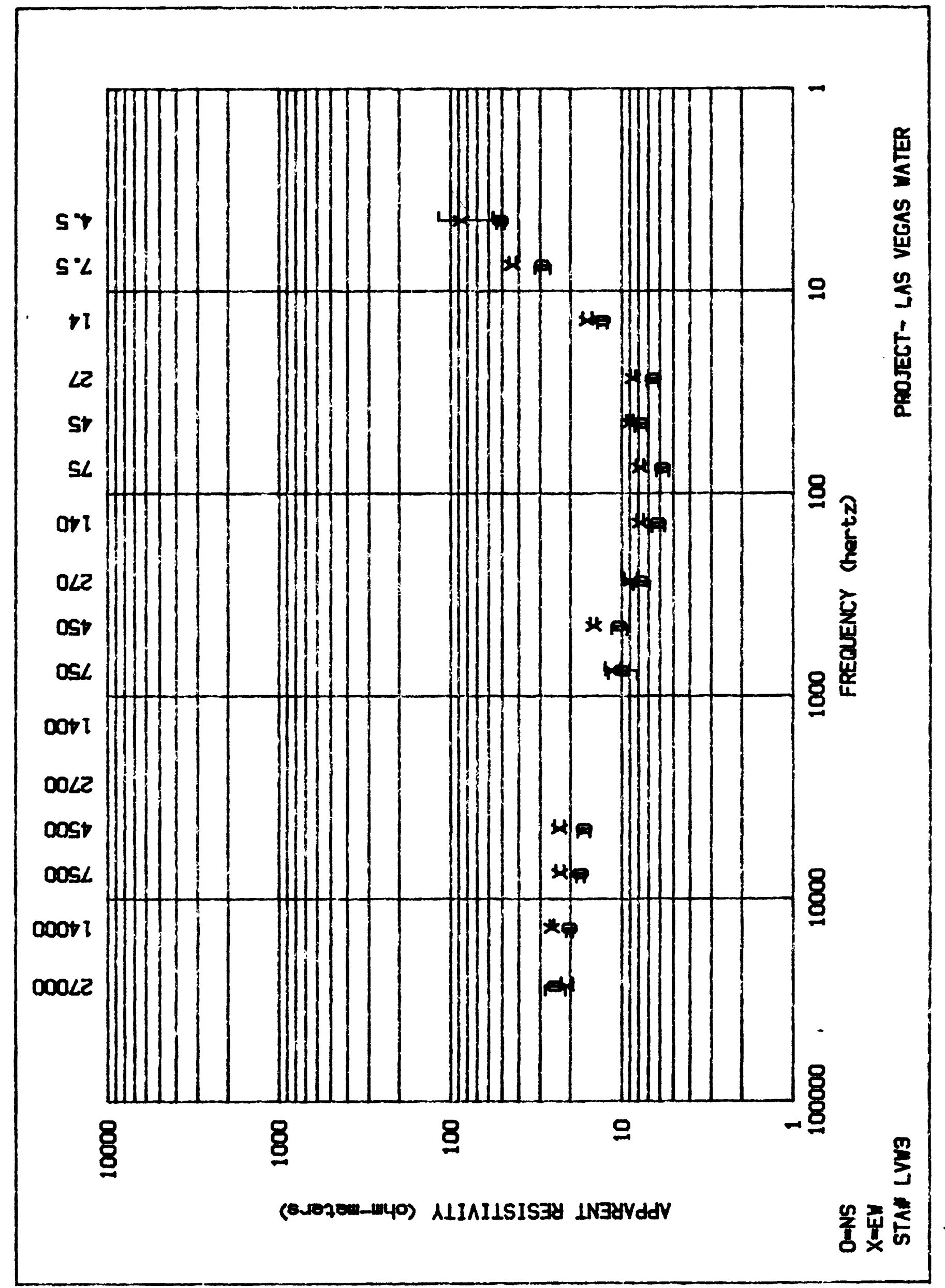




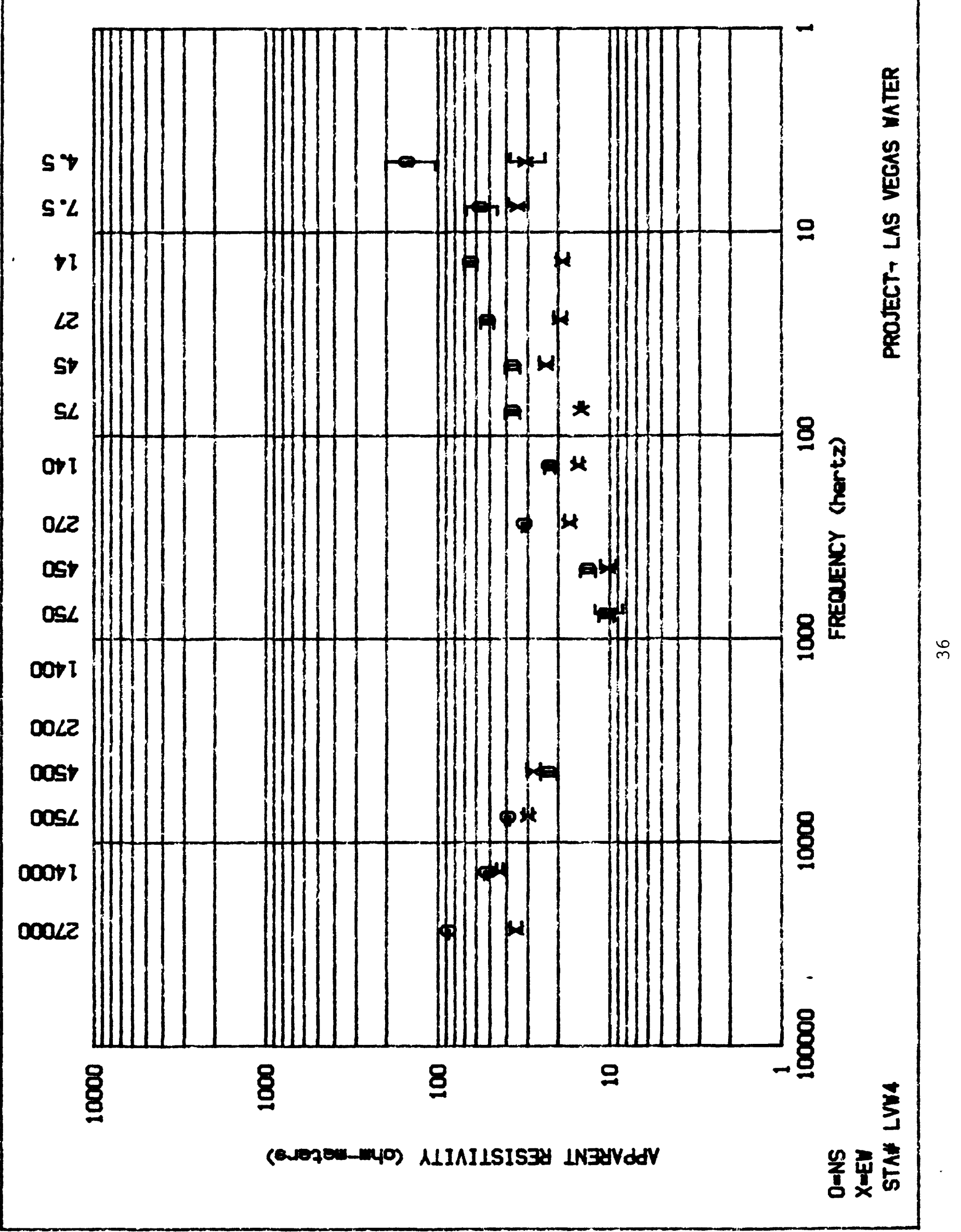




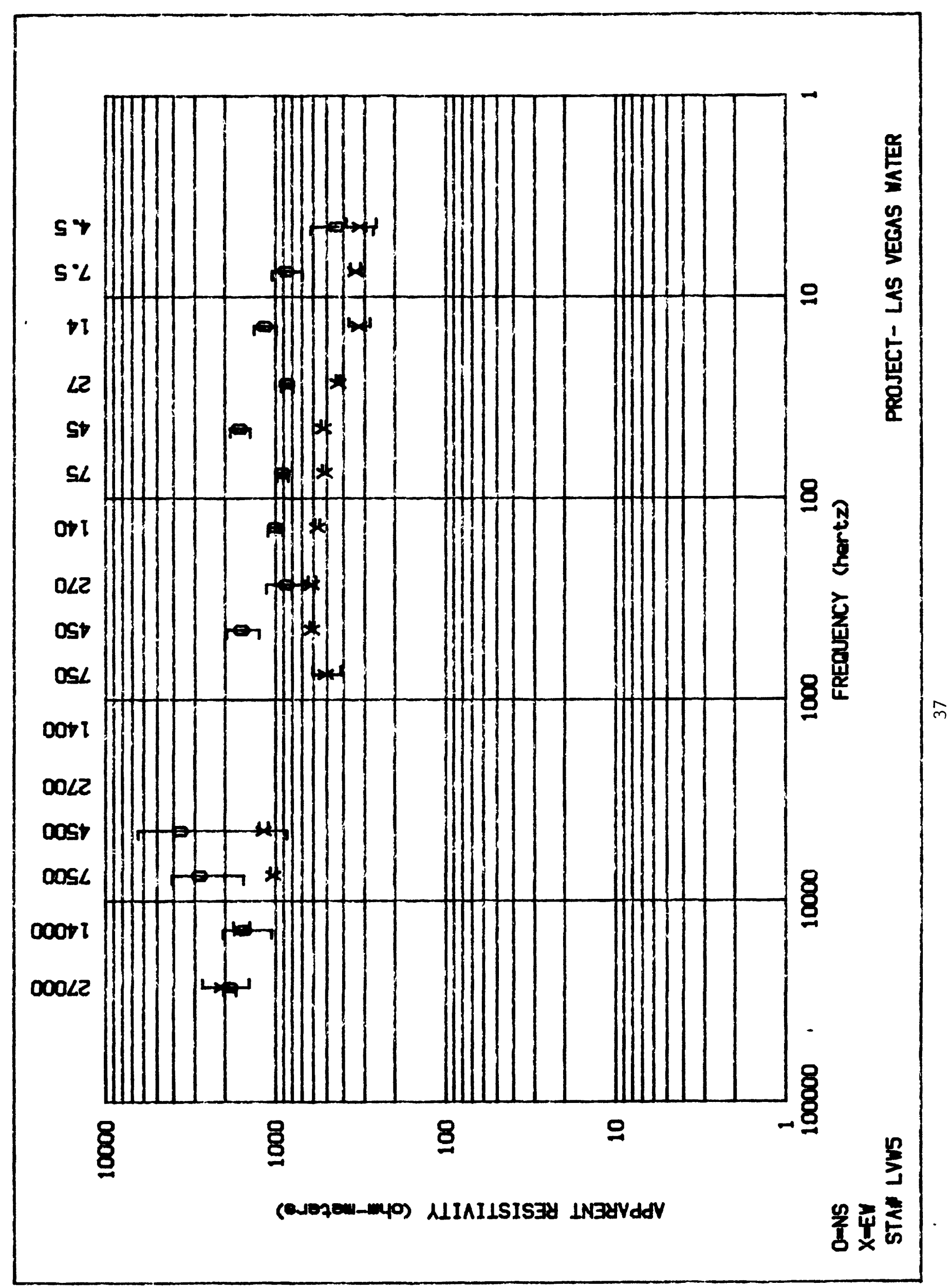




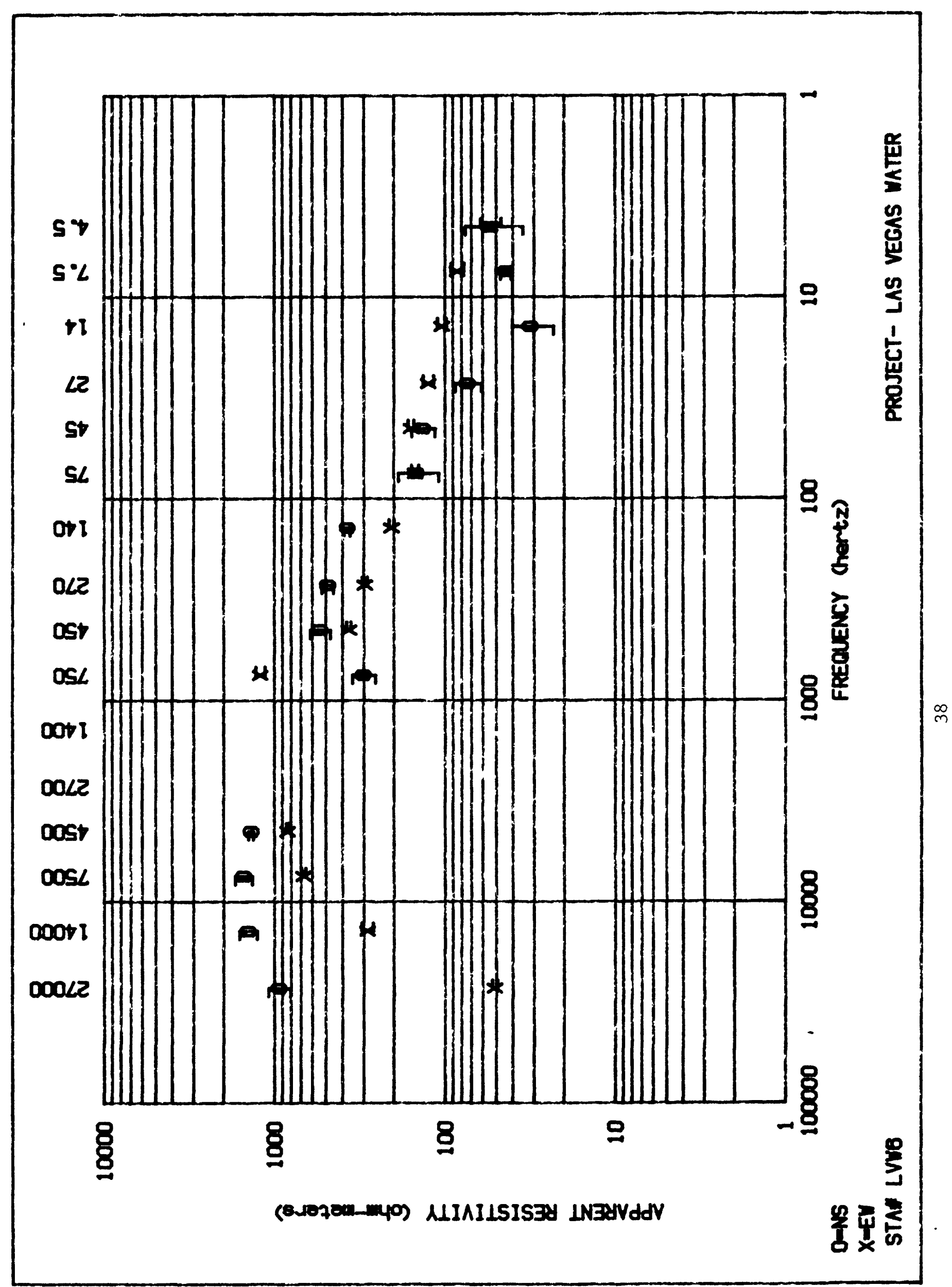




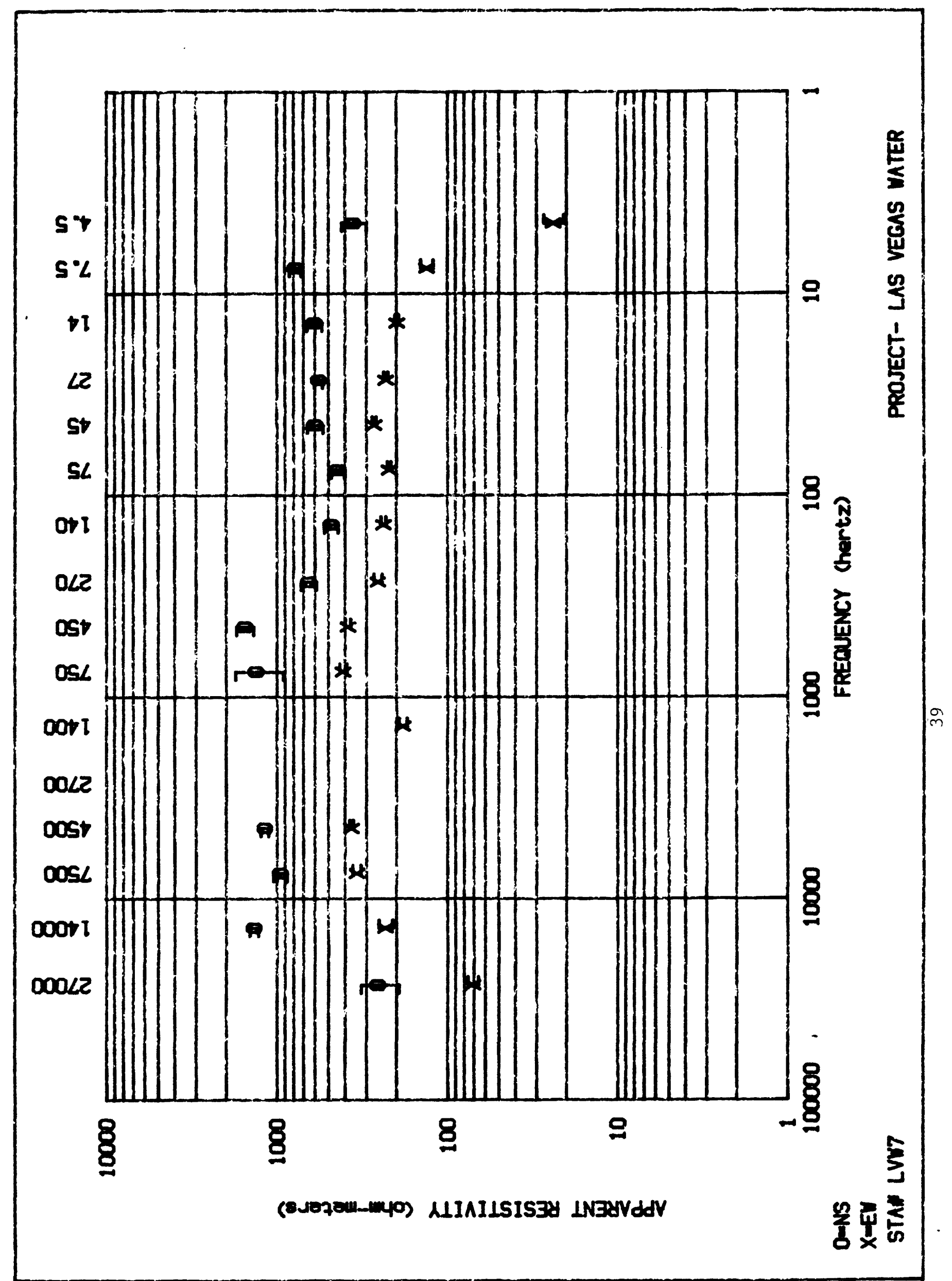




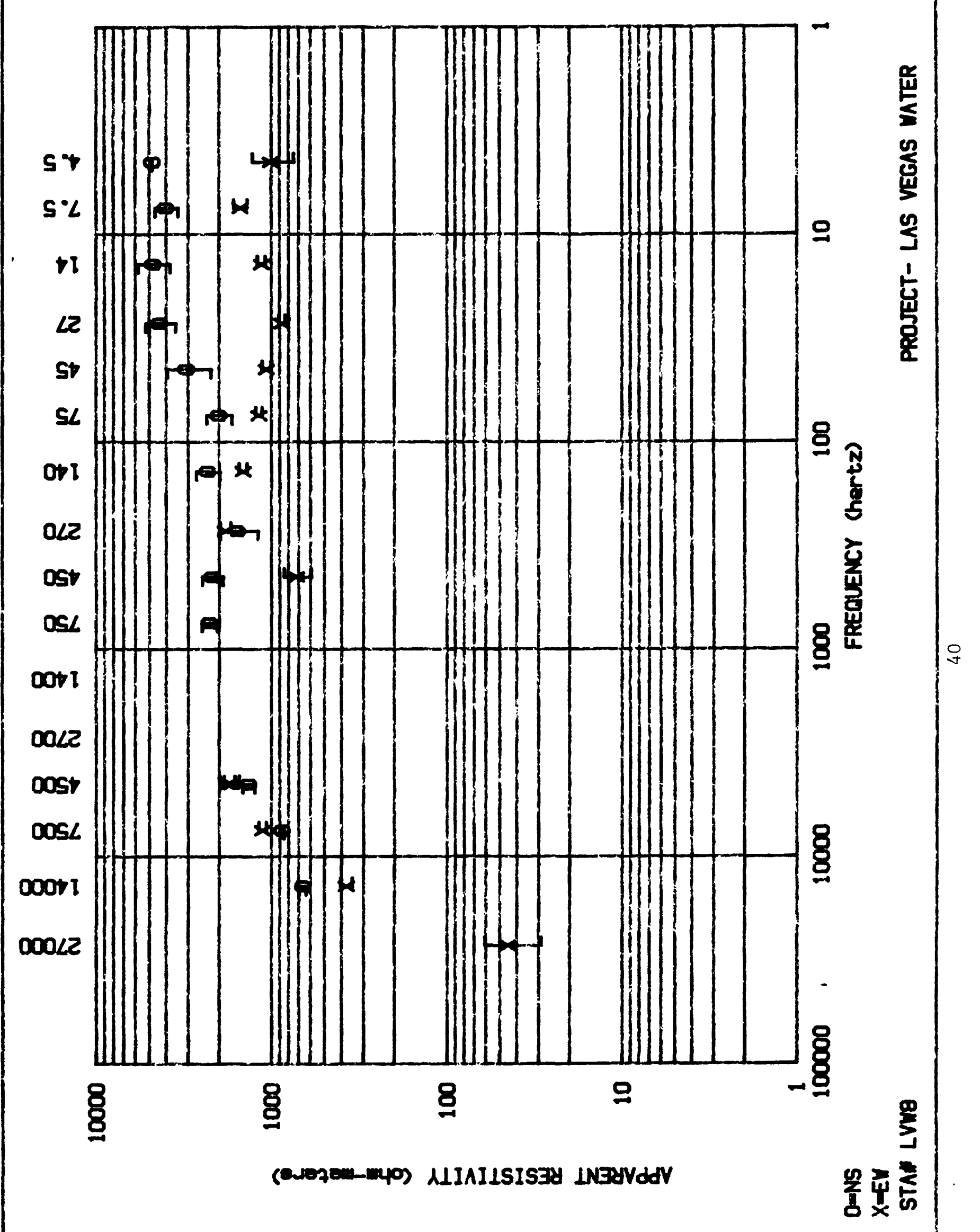




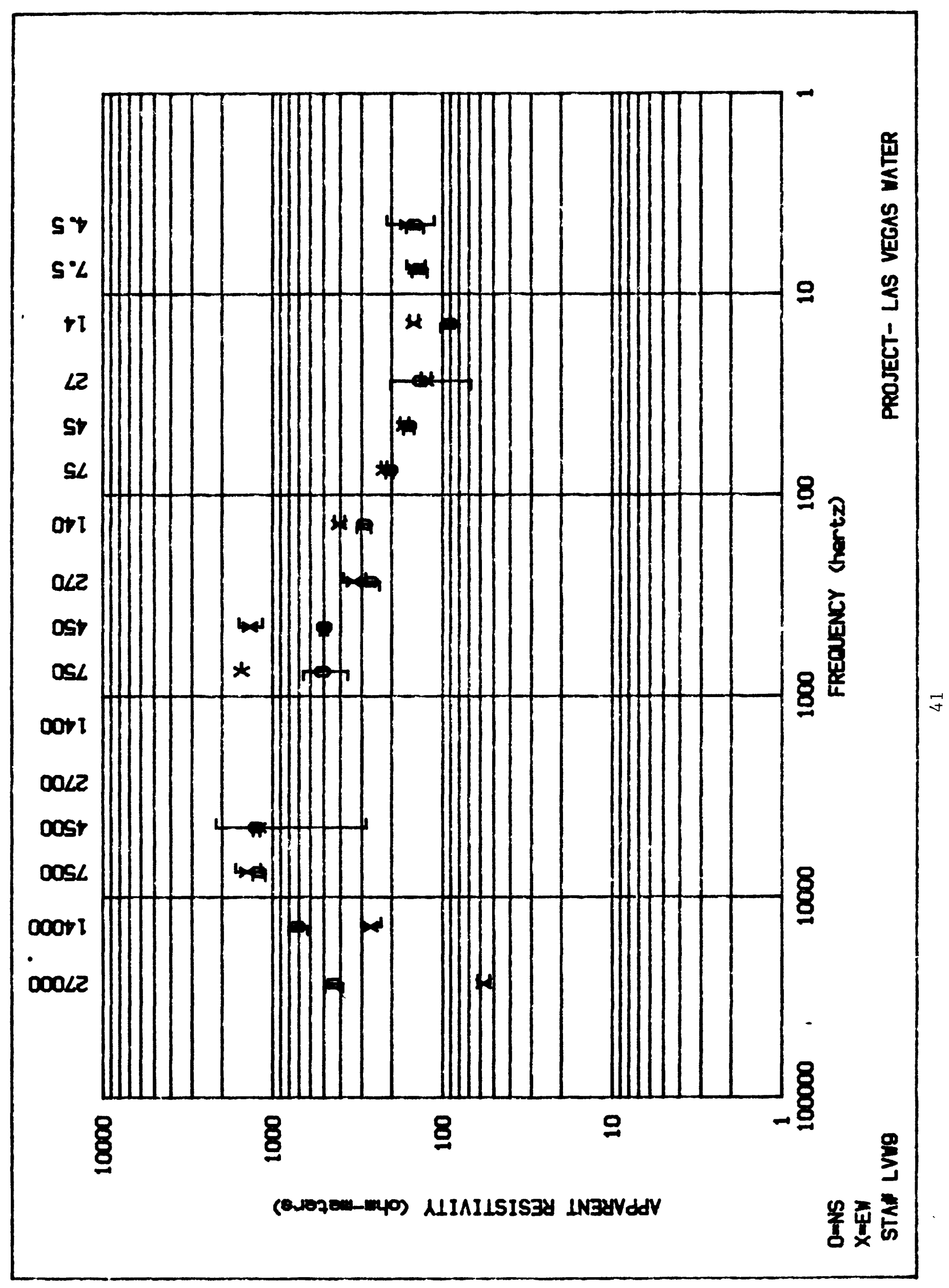




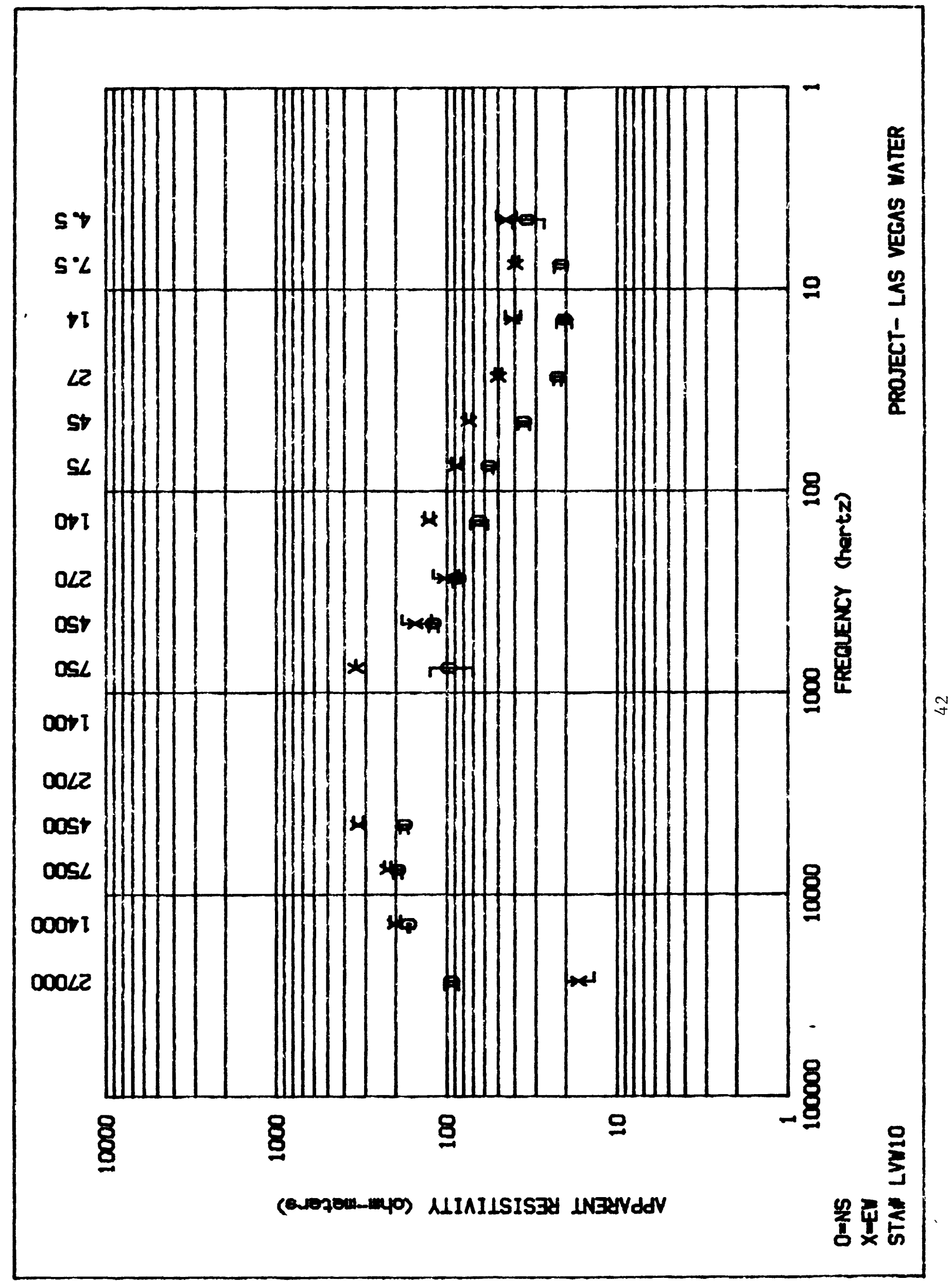




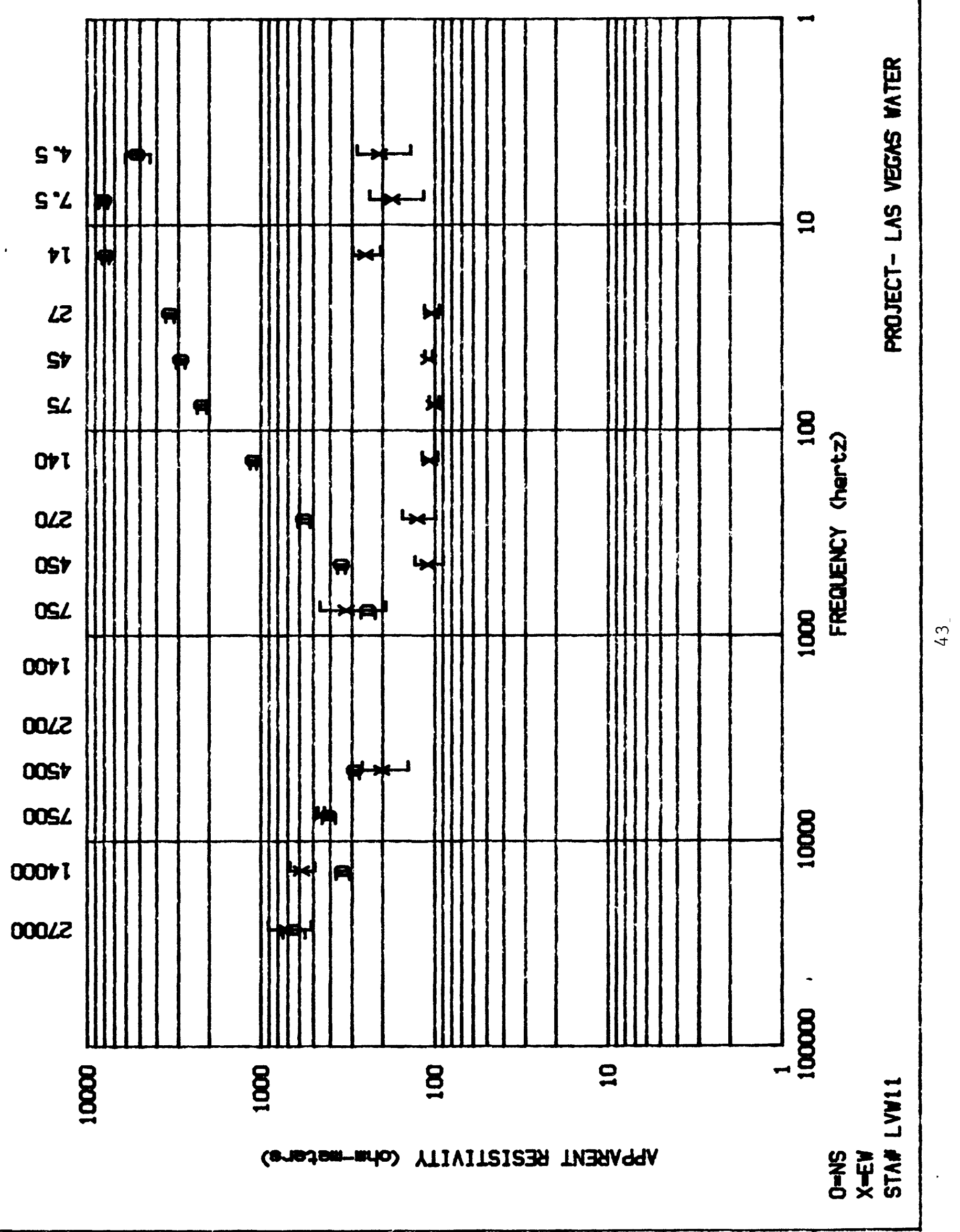




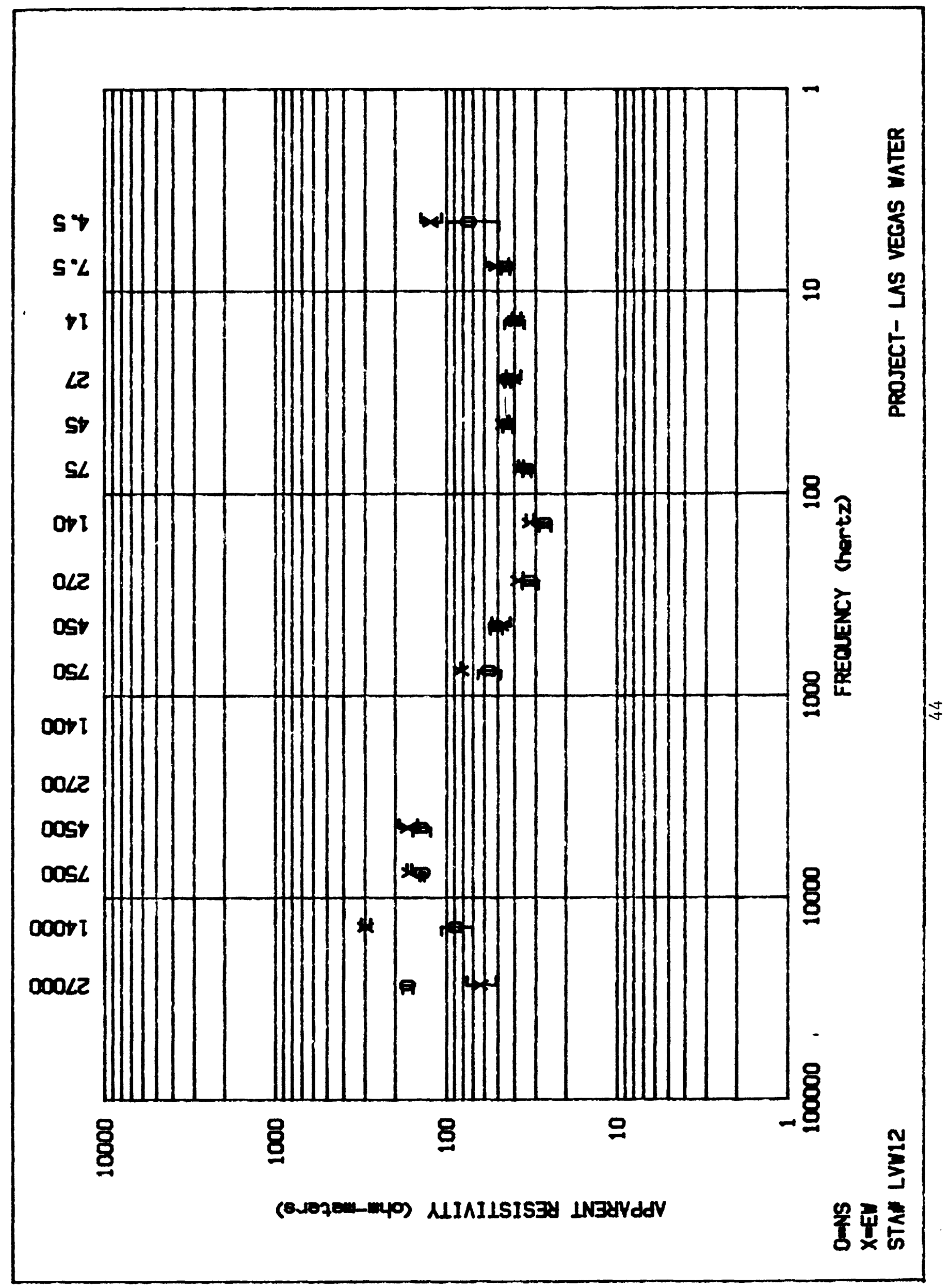




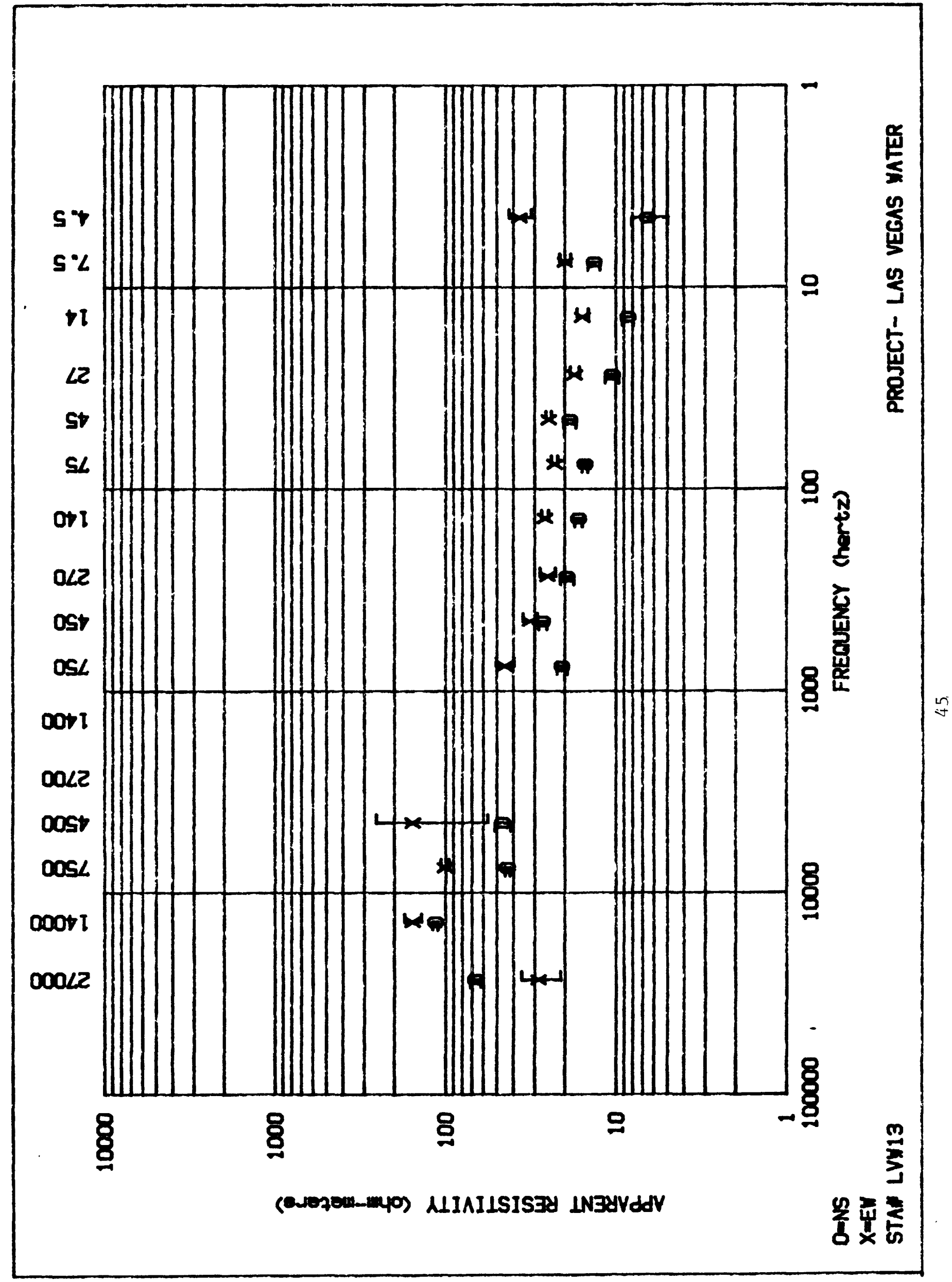




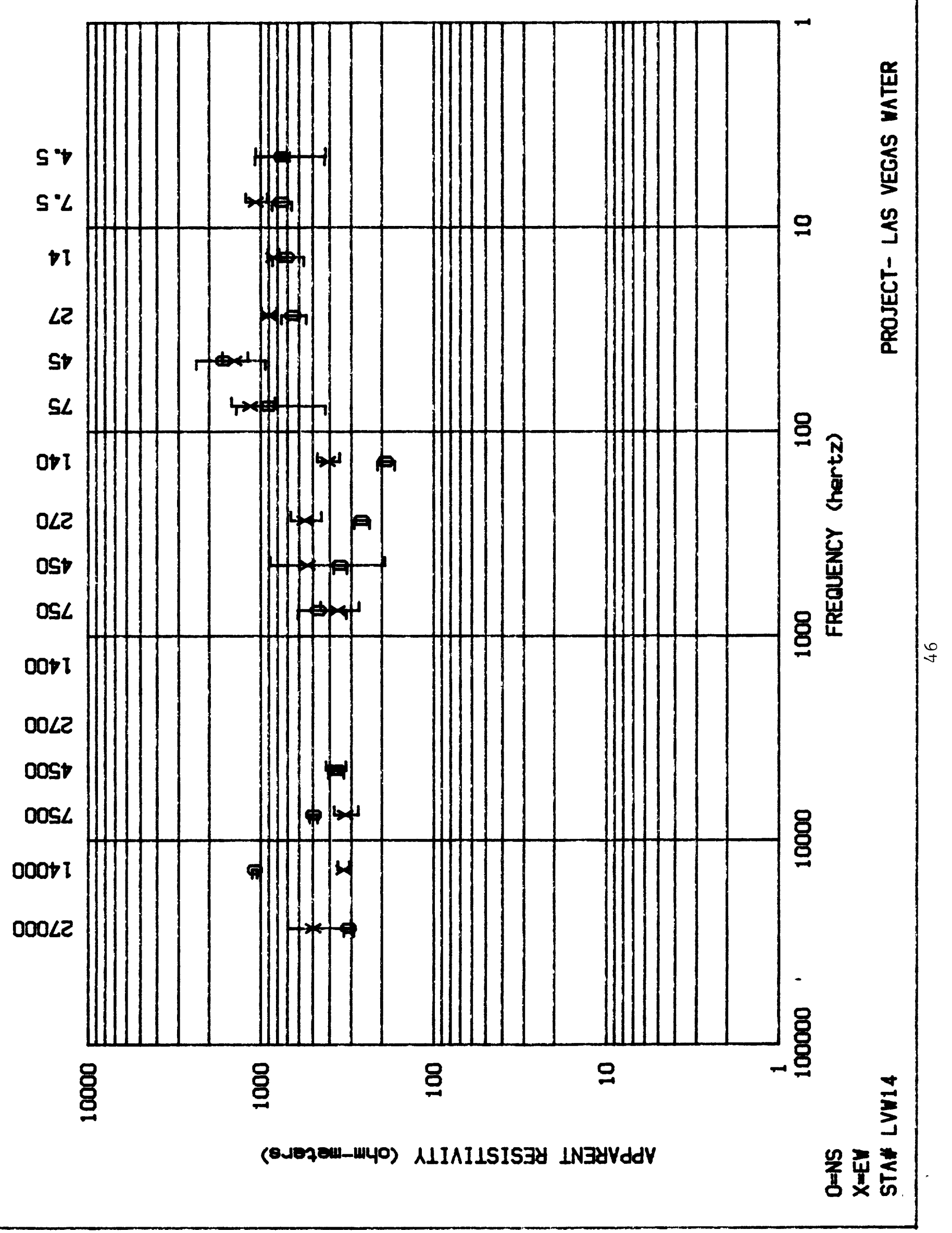




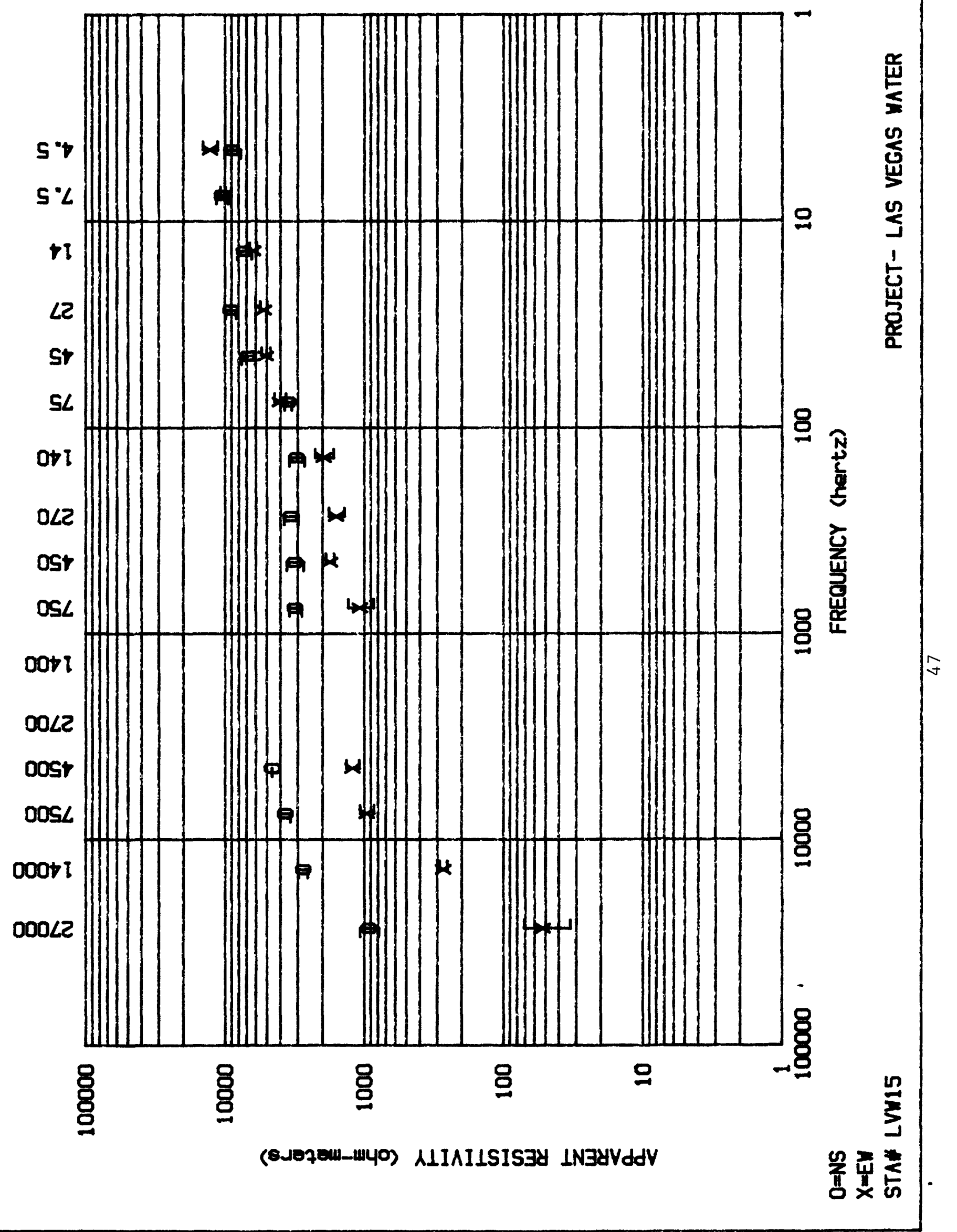




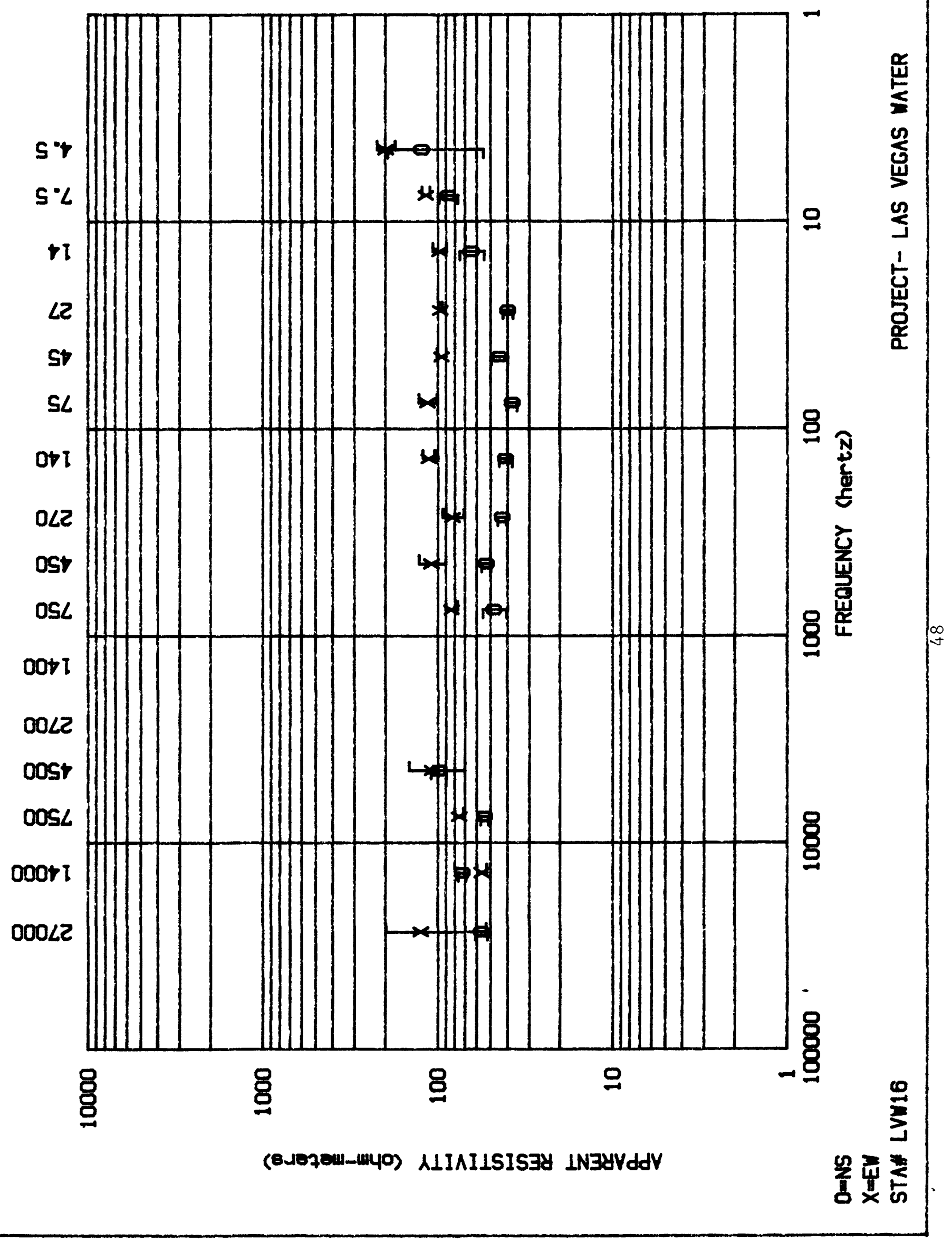

